
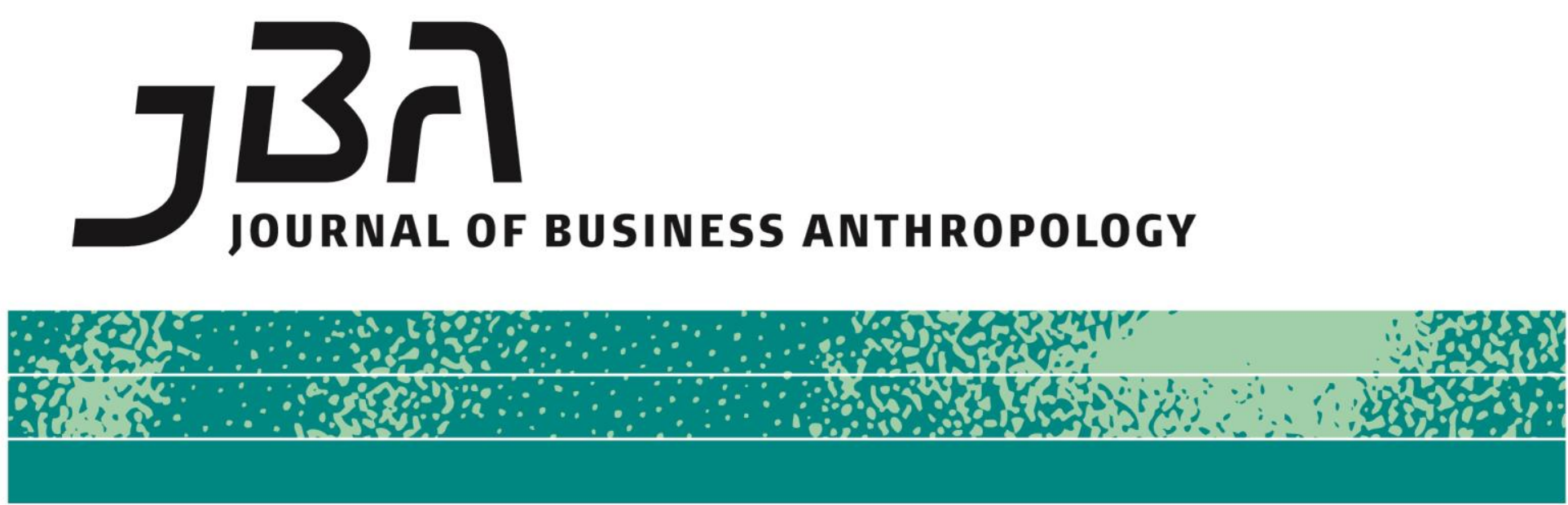

\title{
Opinions: Business History and Anthropology
}

\author{
Walter Friedman, Louis Galambos, Eric Godelier, Gwendolyn \\ Gordon, Geoffrey Jones, Per H. Hansen, Eric W. Orts, Daniel Pope, \\ Philip Scranton, Jeffrey L. Sturchio, and R. Daniel Wadhwani. \\ With an Introduction by Greg Urban
}

\section{Business Anthropologist, Meet Business Historian}

Greg Urban, Arthur Hobson Quinn Professor of Anthropology, University of Pennsylvania

What ethnographer studying an organization hasn't wanted to jump into the time machine, travel back to then, figure how we got from then to now? Take anthropologist Jakob Krause-Jensen. His book, Flexible Firm: The Design of Culture at Bang \& Olufsen, exemplifies the best of modern anthropological corporate ethnography. To grasp the cultural processes inside this Danish company, known for its elegant design of high-end audio equipment, Krause-Jensen, like other ethnographers, looked to the past. Bang \& Olufsen, he reports, was founded in 1925, selling innovative technology for connecting radios to electrical grids. How did it transform itself from those technological beginnings into a paragon of the Danish design movement? What response did it make to the popular audio electronics coming out of Japan? When did its management come to be concerned with creating a distinctive corporate culture?

Business anthropologists often, maybe even always, pay attention
Page 1 of 64

JBA 3(1): 15-78 Spring 2014

(C) The Author(s) 2014 ISSN 2245-4217

www.cbs.dk/jba 
to the history of the firms they study, as Krause-Jensen did. However, many of us have little familiarity with business history as an academic endeavor. Sensing an opportunity, Brian Moeran and Elizabeth Briody wondered whether the journal's readers might benefit from interacting with business historians. Just possibly, they thought, historians would find some nuggets of value in this encounter as well. Because I had recently edited a volume ${ }^{1}$ that included contributions from historians, Brian and Elizabeth asked me to assist in putting together a collection of informal opinion pieces on business history. The result is the set of essays that follows.

Louis Galambos and Jeffrey Sturchio, in the opening piece, begin with an observation. Modern business organizations, they tell us, despite their often global reach, are insular: "The main points of reference for most employees ... are their supervisors and fellow workers, the main concerns on a day-to-day basis the mundane tasks of meetings, presentations, memos and 'deliverables.'” In short, these organizations form communities, or, one might even say, tribes. What better argument could there be for why we need anthropologists studying corporations, why we need the Journal of Business Anthropology?

Lest you think: "they are historians; what do they know about the social life inside corporations today"; let me add that, yes, Galambos is a distinguished professor of history at the Johns Hopkins University, and, yes, Sturchio holds a PhD in the History and Sociology of Science. But Galambos has also worked closely with former Merck CEO, Roy Vagelos, and Jeff Sturchio is also himself a businessman. In fact, Jeff has spent much of his life inside corporations. For many years, he was employed at Merck, eventually working his way up to Vice President for Corporate Social Responsibility. Jeff knows what corporations are like from the inside. He qualifies as at least an honorary "native ethnographer."

While he and Galambos make a case for business anthropology why the study of corporate culture and social life is critical - they also exemplify in their essay what business history is and how it complements business anthropology. They tell the story, beginning in the latter nineteenth century, of how business firms came to incorporate the professions; lawyers and engineers initially, with accountants somewhat independent, then later scientists, psychologists, and other professionals, and most recently - and notably for readers of this journal, of course anthropologists.

If firms were only insular, only inward focused, they could not succeed, Galambos and Sturchio argue, at "delivering the products and services that their customers value enough to purchase." Drawing inspiration from Intel's Chief Corporate Anthropologist, Genevieve Bell,

\footnotetext{
${ }^{1}$ Greg Urban (ed.), Corporations and Citizenship. Philadelphia: University of Pennsylvania Press, 2014.
} 
they show that, by embedding the professions in firms, business organizations countered their own inherent insularity. They brought the world outside corporate walls to the inside.

Are salesmen professionals in the sense Galambos and Sturchio intend? Probably not. But a similar process of corporate internalization has taken place. As Walter Friedman recounts in the next essay, the United States moved from "having an economy populated by peddlers and traveling salesmen to one with highly managed salespeople at places like National Cash Register, Burroughs, Chevrolet, and IBM." During his graduate school days at Columbia University, Friedman had become interested in "how well the image of the salesman depicted in Sinclair Lewis's novel Babbitt (1922) corresponded to reality." But the focus of his book, like so much of business history, concerned change. How did the practice of selling shift or transform over time.

As Friedman tells us, his method for studying change, in keeping with the historian's traditional craft, was to look at written sources - all sorts of documents, from scripts used to sell Singer Sewing machines, to National Cash Register's internal company magazine, to court cases and published personal memoirs. Business anthropologists more typically engage in the observation of activities and interactions, sometimes as participants, or conduct interviews with those who are so engaged. However, in the area of method, as subsequent essays make plain, some overlap has developed. Oral histories today are coming to be accepted sources within business history, just as the ethnographically describable usage of documents has become a focus of interest for some anthropologists. ${ }^{2}$

Friedman's essay also allows us a peek at the scholarly training of a business historian. A key influence in Friedman's case, as in that of so many business historians, was Alfred DuPont Chandler, considered by many the pre-eminent business historian of his time. Friedman foregrounds the big research questions Chandler asked: "Why did large companies emerge in certain industries and not others? Why did companies differ in their organizational structure? Why did large companies emerge in some countries and not others?" The first and third of these questions concern change, but the second looks like a traditional social scientific, even anthropological, question.

This latter similarity may not be coincidental. Friedman notes that Chandler, while a student at Harvard, came under the influence of sociologist Talcott Parsons. Parsons, in turn, had played an indirect role in shaping American anthropology. Among his most celebrated students was Clifford Geertz, the one anthropologist with whom business historians are most familiar - at least to gauge by the number of citations

2 See, for instance, Annelise Riles (ed.), Documents: Artifacts of Modern Knowledge. Ann Arbor: University of Michigan Press, 2006. 
in the accompanying essays. From the perspective of scholarly lineage, therefore, business history and modern cultural anthropology share descent from a common recent ancestor.

A distinct, less America-centric, perspective on business history appears in the essay by Eric Godelier, Professor of Management, Business History and Social Sciences at the École Polytechnique in France. Godelier notes that, in France, anthropology and history have been in dialog since the 1960s, when Claude Lévi-Strauss and Ferdinand Braudel "entered into a famous polemic on the importance of history for anthropologists." Braudel, of course, was known for his work on the history of capitalism, Lévi-Strauss as the founder of anthropological structuralism.

Most of Godelier's essay, however, explores the possible benefits for business historians of engaging with anthropological concepts. His notion of "concepts" is of a high order - culture, myth, institutions. He seems to be suggesting that business historians ought to think more like anthropologists. Indeed, his one mention of Alfred DuPont Chandler occurs in the context of proposing that Chandler's work might be examined within the framework of business myths.

In their essay, anthropologist Gwen Gordon and legal scholar and social theorist Eric Orts, both at Penn's Wharton School, team up to look at the connections between history and anthropology, as Godelier proposes, though mainly in the U.S. context. They argue that anthropology since the 1990s has taken a "historical turn," in which culture itself comes to be understood as "inherently historical." Instead of encouraging historians to think like anthropologists, as Godelier does, they advocate that anthropologists think like historians, at least when it comes to the study of business organizations.

Their main criticism of anthropologists - and here they explicitly exempt business anthropologists - is that they tend to reify the corporation, treating it as a "seemingly seamless, timeless" entity in the world. For the most part, Gordon and Orts claim, anthropologists, apart from those explicitly self-identifying as business anthropologists, tend, on balance, to vilify corporations, as well as those who work within them. This attitude manifests itself, in turn, in "self-flagellation hindsight marked by the mea culpa tone sometimes found in the work of academic scholars" 3 who undertake corporate research. Instead, Gordon and Orts propose, the corporation is actually a historically shifting reality, not an immutable one. By examining the quotidian practices inside corporations, such as business anthropologists now do, anthropology can help to demystify and historicize the corporate form.

If Gordon and Orts argue that anthropologists could benefit from historicizing their understanding of culture, the following essay by Per $\mathrm{H}$.

\footnotetext{
3 Melissa Cefkin M (ed.), Ethnography and the Corporate Encounter: Reflections on Research in and of Corporations. New York: Berghahn Books, 2009, p. 18.
} 
Hansen of the Copenhagen Business School and R. Daniel Wadhwani of the University of the Pacific and Copenhagen Business School looks at ways in which business historians have taken up the culture concept. They are also brutally frank in their assessment, observing: "Business history, as it was practiced for most of the 20th century, had little interest in anthropology and a very one-dimensional view of culture." Only more recently, they observe, has the situation changed.

In their narrative, business history as a discipline took off in the 1920s, with the Harvard Business School publishing the Bulletin of the Business Historical Society beginning in 1926. Until the 1960s, research in business history, they tell us, stressed "the agency of actors, the importance of mind and will in economic processes." In their view, this changed dramatically in the 1960s and 70s with publication of Chandler's books. Structure came to replace agency.

Hansen and Wadhwani are correct, no doubt, that little interchange between anthropology and business history took place during this period. However, I note that the 1960s and 70s were also the heyday, within anthropology, of structuralism, whose main proponent was French anthropologist, Claude Lévi-Strauss, the key thinker foregrounded in Godelier's essay. The fields at this time, therefore, were developing in parallel fashion.

As Hansen and Wadhwani explain, however, the situation began to shift in the 1990s. A "cultural turn" took place in business history that complemented the "historical turn" in anthropology pointed out by Gordon and Orts. The two fields discovered one another. It is against this backdrop that Brian Moeran and Elizabeth Briody came to conceptualize the present collection of essays. The time seemed ripe for a meet and greet in the Journal of Business Anthropology.

In that meet-and-greet spirit, Hansen and Wadhwani propose three specific areas in which conversation might unfold. First is the "uses of history approach," in which historians focus on the instrumental and even conscious deployment of history to achieve goals. This resonates with business anthropology and, indeed, with anthropology more generally, which has long been concerned with the uses of narratives in relationship to ongoing social processes.

The second potential area for discussion concerns what Hansen and Wadhwani dub "contextualization," although the meaning of the term is different in these two disciplinary (dare I say it) "contexts." For historians, the word often refers to epoch, a stretch of past time cutting across some expanse of social space, and is typically beyond the actors' control. For anthropologists, context is more often local and manipulable, as, for example, in the interpretation of a segment of spoken discourse based on the environment of other words in which it occurs, people present, occasion, and physical surround. 
Lastly, Hansen and Wadhwani, in keeping with other essays assembled here, point to a recent blurring of distinctions in method, with more business historians using oral histories to understand corporate pasts. Geoffrey Jones, author of the next essay, in fact, reports that his recent studies, "a company history of the Anglo-Dutch consumer goods giant Unilever since 1965, a history of the global beauty industry, and a forthcoming history of green entrepreneurship, have relied to a growing extent on interviews with managers and entrepreneurs."

Jones is the Isidor Straus Professor in Business History at the Harvard Business School, the position once held by the celebrated Alfred DuPont Chandler, and so it is only fitting that his essay, like that of Hansen and Wadhwani, should provide an overview of the discipline since the 1920s. But the two stories they tell, while factually perhaps the same, are strikingly different in at least two important respects.

First, the account by Jones is soul-searching, the story of a discipline burdened by a "permanent identity crisis," whose practitioners bemoan "that few people read most of their painstaking studies." Business anthropologists will recognize in these remarks some of their own angst as regards positioning within the broader field of anthropology. Jones remarks that at Harvard, he is in the business school, where managers get trained. Before that, he had taught in Europe in economics departments. He was never a faculty member in a department of history. The relationship to academic history is, as he describes it, fraught. Much the same can be said of business anthropology, though its position within academic departments of anthropology may be gradually improving.

Second, Jones's story is distinctive not just owing to the narrative of business history's marginalization. More significantly, and unlike many others, his story highlights the need for "generalization and conceptualization," and a tolerance for "abstraction." Anthropologists have for some time been fearless when it comes to conceptualization and abstraction, as can be seen in the exemplary ethnography with which I began this introduction. While a first-tier ethnographer of the Bang \& Olufsen company, Krause-Jensen is no stranger to abstract theory. On the contrary, substantial sections of his book are focused on it, as when he takes to task the basic underlying assumptions approach to corporate culture promulgated by Edgar Schein. His ethnographic account, too, is interwoven throughout with conceptual discussions.

Here then is a possible area of convergence between business history and business anthropology - one, in fact, that harkens back to the relationship between Chandler and Geertz as students of Talcott Parsons. Indeed, Jones, together with Walter Friedman, would like to see within business history "a renewed focus on central issues" capable of capturing broader scholarly attention - "innovation, entrepreneurship, and globalization"; "business and the environment, government, and democracy." 
If the kinship between anthropology and business history traces back to Talcott Parsons, the broader relationship between the parent disciplines has decidedly more ancient roots. I recall, as an undergraduate at the University of Chicago, taking a class in anthropology in which the professor told us straightforwardly: Herodotus was the first anthropologist; through his travels, he documented the variation in customs around the ancient world. Period. Having already read the Persian Wars in a required humanities seminar, I was mildly surprised. In that context Herodotus was unquestionably a historian. There was no reference to his study of exotic customs. The focus was his narrative line. So I was delighted that Philip Scranton, Board of Governors Professor of History Emeritus at Rutgers University, and Editor-in-Chief of Enterprise and Society: The International Journal of Business History, opened his essay with a quote in which Herodotus gets described as "a reporter, an anthropologist, an ethnographer, a historian."

In addition to providing a nuanced account of how business history and business anthropology intersect, Scranton offers a key theoretical insight - one at a high level of abstraction, as Jones calls for, and one susceptible to generalization. Actors, he asserts, "retrospectively fashion rational orderings of non-linear, indeed chaotic or sloppy, efforts." To counter such rational unfolding narratives, he proposes that researchers "marshal documentation that presents agents looking forward into buzzing alternatives, armed with fragmentary information, rule-of-thumb analogies, and incomplete knowledge about the backgrounds of, and environments for, decision-making." Only in this way can we hope, ultimately, to comprehend "historical dynamics."

Scranton offers us a peek, along these lines, at his recent research on the jet propulsion industry in Britain, France, and U.S. from the Second World War to the early 1960s. As he dug deeper in the archives, he explains, he found information contradicting the "triumph of reason" stories told about the development of jet propulsion. "The closer to the design offices and engine test-beds I could get," he writes, "the more unruly the development process appears." He was able, finally, to uncover the "cascades of errors, failures, and fixes that, in time and at staggering costs, yielded reliable military jet engines."

One senses here a kinship with older anthropological accounts of "primitive" rituals and myths, communal life pulsating with primary process, steeped in affect, best by chance. At the same time, the historical dynamics in Scranton's case are distinct. Whereas a reflexive orientation to preserving the past, carrying out the rituals as the ancestors had done, prevailed in the societies studied by early anthropologists, business corporations today, and the jet propulsion industry studied by Scranton in particular, are explicitly - what I would call metaculturally - oriented to producing the new, bringing into this world what has not heretofore existed. Indeed, corporations, one might contend, are key institutional 
loci for the creation of new culture.

How fitting that in the final essay of this collection, Daniel Pope, History Professor Emeritus at the University of Oregon, should single out Scranton as "one of the leading figures in newer - perhaps more anthrofriendly - scholarship in American business history," setting Scranton's work in opposition to the older Chandlerian paradigm. He observes that, while in his scholarly writings Scranton did not acknowledge anthropological debts, his "attention to language and imagery, labor, gender, technological change and resistance, consumer behavior, style and fashion" should make cultural anthropologists feel comfortable.

Taking off from Scranton, Pope reviews a spectrum of writings in this newer vein, from accounts of consumption, to studies of advertising, research on work and labor, and even two firm-specific books: one on RCA and the other on Wal-Mart. Reading his vivid overview, I note that Pope's understanding of cultural anthropology is strongly influenced by Geertz. He goes so far as to confess that, in his own book on the advertising industry, he pled nolo contendere to charges of economic determinism, apparently suspecting that anthropologists would shriek with horror at such an abomination. He has since learned, he explains, that "advertising history can be sensitive to cultural context without neglecting its business functions." Readers of this journal will be well aware that anthropology spans a breath-taking range of theoretical orientations, including those that could be labeled economic determinist.

In concluding this introduction, I find myself in awe of the stature and accomplishments of the business historians who contributed to this collection. From Galambos to Pope, assembled here is a veritable who's who of business history. I have half a mind (perhaps it is my better half) to leave this introduction at that, and let readers loose on the essays themselves.

The other half of my mind, however, houses an anthropologist trained in the 1970s, one hardly averse to what Jones calls "generalization and conceptualization;" one, moreover, with a high degree of tolerance for "abstraction." So I will sally forth, weaving together some threads from these provocative essays.

The essays suggest a threefold comparison between business history and business anthropology: as regards object of study, methods for studying it, and concepts pertaining to it. These essays by and large take the object of business historical study to be the past, and of business anthropological research to be present-day culture. Further, they take the methods to be the study of written documents in the former case, spoken words, behaviors, and material artifacts in the latter. The essays speak to some measure of boundary blurring, as already noted. So much seems straightforward.

More difficult is the conceptual realm. As Pope asserts in his 
opening remarks, historians have been "resistant to the siren calls of theory," instead burrowing into sources, constructing evidence-based narratives." Yet references to concepts and generalizations abound in these essays. One key notion is change. The word appears on many of the subsequent pages. Several essays link business history to the study of change, implicitly assuming that anthropology, even in its newfound orientation to historical time, is interested in something else. What is that something else? In traditional anthropology, the something else is continuity or persistence. Indeed, in some ways when anthropologists even today look at history, they are really most interested in ferreting out if not continuity, then at least the patterns of culture and social relations that constrain the direction of change. We might say that the complementary questions posed by our disciplines when we examine a stretch of historical time are: what's different (history), and what's the same or similar (anthropology).

Amidst the discussion of concepts, from institutions, culture, and myth to context, power, and rationality (along with irrationality), I single out one as central in the encounter between business historians and anthropologists. This is the idea of contingency, that chance intervenes, that trajectories are not wholly determined. Business historians appreciate this much more than anthropologists do. In the anthropologist's study of social and cultural patterns in the present, contingency is not readily discernible. We discover pattern; we do not perceive the chance that may have produced it. In my view, this is why history is so indispensable a complement to anthropology.

At the same time, pattern is constraining of change and resists the entropic forces of contingency. For this reason, I - and here I plug my own idiosyncratic theorizing ${ }^{4}$ - find that the proper object of study for anthropology and perhaps also history is cultural motion, how and why cultural elements (whether symbols such as corporate logos, values, sayings, stories, or patterns of social relations) tend to move across space and through time. A careful ethnographic study of a business corporation or of any community, for that matter, reveals a culture that is far from uniformly distributed in the present. We discover differing degrees of dissemination, varying pathways along which culture moves. We find that culture gets corrupted and changes in the course of its movement. We suspect the same is true of long-term historical trajectories. What forces account for the persistence of pattern? What forces account for changes? These are questions both disciplines can and ought to ask.

So much for pontification. Onto the substance of the encounter: business anthropologist, meet business historian.

\footnotetext{
4 For example, Greg Urban, Metaculture: How Culture Moves through the World. Minneapolis, MN: University of Minnesota Press, 2001.
} 


\section{Life in the Corporation: Lessons from Business History}

Louis Galambos, Co-Director, Institute for Applied Economics, Global Health and the Study of Business Enterprise, Johns Hopkins University, and

Jeffrey L. Sturchio, Senior Partner, Rabin Martin, and Visiting Scholar, Institute for Applied Economics, Global Health and the Study of Business Enterprise, Johns Hopkins University

Few who have not worked in or studied modern multinational corporations up close realize how insular they can be. Despite being global organizations that may operate in more than 100 countries, with tens of thousands of employees who interact daily with millions of customers and countless politicians, regulators, policy influentials, journalists, investors, advocates and community representatives, there is a strong cultural bias to look inward rather than outward. The main points of reference for most employees in corporations are their supervisors and fellow workers; the main concerns on a day-to-day basis the mundane tasks of meetings, presentations, memos and "deliverables." To an extent surprising to those on the outside, the quotidian rhythms of corporate life are dominated by priorities, processes and practices that are too readily divorced from the world in which the corporation's customers and communities live. If these tendencies operated without mediation, it would be hard to understand how most businesses could succeed at delivering products and services that their customers value enough to purchase.

What successful corporations learn to do is find ways to bridge the gaps between internal structures and the external world of customers and other stakeholders who buy their products and provide the revenues that keep the corporate engine running. As Genevieve Bell, Intel's chief corporate anthropologist, astutely observed in a recent New York Times profile: "my mandate at Intel has always been to bring the stories of everyone outside the building inside the building - and make them count. $^{5}$

5 "The Watchful Lab of Dr. Bell," New York Times, 16 February 2014, p. BU1. http://www.nytimes.com/2014/02/16/technology/intels-sharp-eyed-socialscientist.html?src=xps. You may find amusing an earlier commentary on the emerging role of anthropologists in business, which noted that they "....are no 
This is a profound insight about how people inside the corporation make sense of their world and connect it to the many worlds outside their organizations. Our view is that Dr. Bell's observation applies beyond the perspective of business anthropology. Indeed, it helps us to understand how life inside the corporation is informed by the wants and needs of the communities in which businesses live and work and of the consumers who buy and use their products and services; the interests and insights of the professional and disciplinary communities that relate to corporate operations and management; and the broader cultural and economic contexts of the multinational environment in which modern corporations create and add value to society.

What are the social processes by which corporate executives "bring the stories of those outside the building inside the building"? How do they "make them count"? We believe that two of the most important mechanisms by which senior executives and managers learn about critical external trends and interpret them for their internal constituencies are through the relationships of professionals who have come to populate a range of specialized functions within the corporation over time and the social networks (both inside the organization and across organizational boundaries) that play an important role in effecting corporate change. Another, related theme is how corporate cultures - and the way senior leaders express their key tenets - provide an important guide to the myths, heroes, rituals and practices that frame the context in which individual professionals pursue their work. ${ }^{6}$

In this brief commentary, we will explore the evolution of these three themes - the evolving roles for professionals in business, the critical function of social networks in understanding how companies function, and the enabling power of a common cultural vision - from the perspective of business history, a discipline that has developed in parallel with business anthropology. As business historians, we are concerned mainly with explaining change over time by understanding the complex, contingent interaction of economic, social, cultural and political factors on organizational practices. ${ }^{7}$ These perspectives complement those of ethnographic research on the corporation and provide useful lessons that

longer detached, pith-helmeted observers, but are getting involved in shaping corporate strategy." "Off with the pith helmets," The Economist, 11 March 2004.

6 For a classic account, see Terrence E. Deal and Allan A. Kennedy, Corporate Culture: The Rites and Rituals of Corporate Life (New York: Basic Books, 1982).

7 There is a rich and growing business history literature. For an introduction, we recommend the following books, which also illuminate further the themes of this essay: Franco Amatori and Geoffrey Jones, eds., Business History Around the World, Comparative Perspectives in Business History (New York and Cambridge: Cambridge University Press, 2003); Kenneth Lipartito and David B. Sicilia, eds., Constructing Corporate America: History, Politics, Culture (New York and Oxford: Oxford University Press, 2004); and Philip Scranton and Patrick Fridenson, eds., Reimagining Business History (Baltimore, Maryland: Johns Hopkins University Press, 2013). 
resonate with the approaches of business anthropologists. ${ }^{8}$

Let's turn first to an historical perspective on the role of professionals in business. ${ }^{9}$ In the late nineteenth and early twentieth centuries, most American businesses had minimal contacts with the professions. The three dominant professions of the nineteenth century were the clergy, doctors, and lawyers. Only the law was at that time of particular interest to businessmen, few of whom had any professional training. Lawyers had become increasingly important to large enterprises, and the railroads had generated so much legal business that they had begun to absorb all of the time of their leading attorneys. In effect, the railroads began gradually to internalize the legal function. Similar changes took place in industry as the merger movement took hold and the legal business of the major firms rapidly expanded, along with the output of their goods and services. Accounting, like law, was one of the three professions that glided into the business system with a minimum amount of friction. The traditional accounting firms had a long history of service to business and they maintained a degree of separation from their clients, in part to satisfy their professional values and in part to assure investors that their financial reports were accurate. As industrial firms expanded, however, they began to bring accountants as well as lawyers into the firm. They helped control the sprawling operations of national and international businesses and provided an interface with the company's auditors. In both cases, as well as with later professional groups, as firms expanded their activities, the internal economy of the organization began to provide a rationale for bringing these functions inhouse. ${ }^{10}$

Engineers were the third group that moved rather effortlessly into modern business - particularly in the technical industries that drove the

\footnotetext{
${ }^{8}$ We are tyros when it comes to the subject in which regular readers of this journal are expert, but we found the following studies instructive: Oana Brindusa Albu et al., "What is business anthropology? An ethnographic study of an explorative workshop," Journal of Business Anthropology, case study \#5 (Spring 2013); Clifford Geertz, The Interpretation of Cultures (New York: Basic Books, 1973); Fred Luthans and Ivana Milosevic et al., "Reclaiming 'Anthropology: the forgotten behavioral science in management history' - commentaries," Journal of Organizational Ethnography 2, no. 1 (2013): 92-116; Brian Moeran and Christina Garsten, “What's in a name? Editors' introduction to the Journal of Business Anthropology 1, no. 1 (Spring 2012): 1-19; and Greg Urban and Kyung-Nan Koh, "Ethnographic research on modern business corporations," Annual Review of Anthropology 42 (2013): 139-158. Urban and Koh's review - focusing on the intercalating effects of corporations on their stakeholders and environments, as well as the inner working of corporations as small-scale (or even large-scale) societies - was particularly helpful as we thought about how business history can speak to business anthropology.

${ }^{9}$ The next three paragraphs draw on our unpublished paper on "Cracks in the glass ceiling: business and the professions," presented at the annual meeting of the Organization of American Historians, April 2014.

10 Paul Miranti, Accountancy Comes of Age (Chapel Hill: University of North Carolina Press, 1990).
} 
second industrial revolution and transformed the economic landscape from the mid-nineteenth century until World War I (from railroads, telegraphs and the telephone, to chemicals, electricity and the automobile). While the engineering culture embraced "workmanship," those values actually blended rather easily with the corporate cultures of their employers. There may have been grumbling, but there was not a revolt. There was also widespread recognition in many of the nation's largest firms, from about 1900 on, that science-based innovation could be a fertile source of profits or a dangerous source of competition. But even the largest firms were slow to internalize research, in large part because the executives were uncertain whether they could successfully manage talented scientists (or even scientists who were not very talented). It was difficult to hire them if you were not trained in science and even more difficult to develop budgets for what they did. All too often the scientific research embodied uncertainty, rather than the more calculable category of risk. When internalization of research became necessary, businesses had to create an entirely new organizational role - the research manager - to handle the interface between the scientists and the firm's executives. Over time, following the example of pioneers like Willis Whitney at General Electric, C. E. K. Mees at Eastman Kodak, and Charles Reese at DuPont, executives in industrial sector after sector came to see both that scientific research could be made to contribute more predictably to product/process innovation and market growth, and that research managers could become just that - managers of a new function that became integral to the firm's competitive fortunes. This transformation occurred fairly rapidly in historical terms: from fewer than 50 industrial research laboratories in American industry in 1900, the number grew to nearly 300 on the eve of World War I and nearly 1000 by 1929.11

From the 1940s on, the borders between business and the professions rapidly eroded. The incorporation of specialized new roles in the functioning of the corporation continued apace, catalyzed by the expansion of business education after World War II and the impact of the G.I. bill and the economic expansion of the 1940s and 1950s. In those years, the Masters of Business Administration became a common doorway to a business career, and as the new, giant multi-divisional firms spread through the American economy and overseas, the demand for new

11 Arnold Thackray, Jeffrey L. Sturchio, P. Thomas Carroll and Robert Bud, Chemistry in America, 1876-1976: Historical Indicators (Boston, D. Reidel, 1985), Table 5.4 pp. 345-46. The General Electric experience was typical of what was happening during these decades: W. Bernard Carlson, Innovation as a Social Process: Elihu Thomson and the Rise of General Electric, 1870-1900 (New York: Cambridge University Press, 1991); Ronald R. Kline, Steinmetz: Engineer and Socialist (Baltimore, Maryland: Johns Hopkins University Press, 1992); and George Wise, Willis R. Whitney, General Electric and the Origins of U.S. Industrial Research (New York: Columbia University Press, 1985). David A. Hounshell and John Kenly Smith, Science and Corporate Strategy: Du Pont R\&D, 1902-1980 (New York and Cambridge: Cambridge University Press, 1988), do an excellent job of describing and analyzing this aspect of corporate evolution. 
MBAs seemed to grow even faster than the rapidly expanding supply. This new generation of business leaders was less hostile to well-educated professionals than their predecessors had been. Recognizing that they operated in a knowledge economy, they were open to substituting professionals in human resources for the old industrial relations crew that had been handling unions and collective bargaining. This was one of a range of transitions that brought a new level of professionalization to America's businesses. Staff work was transformed in the so-called "American Century" of business expansion. Master's degrees proliferated, and even Ph.D.'s found new homes and new respect in postwar business. Marketing became a social science, and psychologists, sociologists and even anthropologists found their niches as companies brought new rigor to understanding their markets and consumers. Companies recognized the need for personnel trained in economics and statistical analysis. The relationships between science and business were no longer strained as they had been in most firms before WWII. In some industries, in fact, the scientists were in such strong positions that they dominated the exchanges with departments of marketing and production. In part, this was a cultural phenomenon, reinforced by successful additions to the bottom line. By the end of the twentieth century, the professions were deeply planted in American business. ${ }^{12}$

These new professional cadres brought with them new networks of relationships whose influence crossed the boundaries between the firm and its outside environments. These connections brought new knowledge and new perspectives to managers of business organizations as they navigated the competitive landscape. Indeed, the extent to which they were able to bring the outside in (in Genevieve Bell's provocative metaphor) proved in many cases to be an important new source of competitive advantage. The business history literature provides many examples of the importance of these professional networks. An early case is that of the synthetic dyes industry, where relationships among academic laboratories, government institutions and entrepreneurial companies help to explain the complex evolution and shifting leadership within this industry across Germany, Great Britain and the United States during the nineteenth and early twentieth centuries. Companies that maintained close ties - usually through their own scientists - with the centers of new organic chemical knowledge fared better than those that looked inward. ${ }^{13}$

\footnotetext{
12 This story is the focus of Louis Galambos, The Creative Society - and the Price that Americans Paid for It (New York and Cambridge: Cambridge University Press, 2012). See also Galambos, "Technology, political economy and professionalization: central themes of the organizational synthesis," Business History Review 57 (Winter 1983): 471-493.

13 Johann Peter Murmann, Knowledge and Competitive Advantage: The Coevolution of Firms, Technology and National Institutions (New York and Cambridge: Cambridge University Press, 2003).
} 
The importance of these social networks - centered on professional scientists who made the transition to industry and involving a complex mix of academic, government and medical institutions - also emerges from case studies of the evolution of the vaccine business of Merck \& Co., Inc. over the century from 1895 to 1995 and the transition to biotechnology in the pharmaceutical industry during the period from the 1970 s to the 1990 s. $^{14}$ In the latter case, pharmaceutical firms that prospered in the shift to molecular genetics and recombinant DNA technology were those that developed internal capabilities to assess the new science while also working creatively to develop alliances with small, entrepreneurial biotechnology firms to innovate in new therapeutic categories. The ability of corporate scientists to move across the boundaries between the academic and industrial communities and to interpret the languages and cultures of each to the other was a critical element explaining the differential success of large pharmaceutical companies in adapting to the new world of biotechnology.

This point about the creative power of networks across organizational boundaries applies with equal force to other areas of corporate activity, as well as to the workings of the internal networks that enable corporations to get things done. Informal networks operate side by side with formal hierarchies within the modern corporation. Just as $R \& D$ leaders depend on key individuals on their teams who have close ties to a range of external experts to import new insights and information into new product development, so do leaders of finance, marketing, production and other functions. In analogous ways, internal networks function to accelerate the diffusion of new ideas, methods and processes throughout the organization. We're all familiar with the role of key individuals in our own organizations: they always seem to know just whom to call, or which article to read, to solve a vexing problem. The intriguing aspect of how these networks operate is that the more diverse the connections we have, the more likely networks will yield just the right insights for critical problems. ${ }^{15}$ Malcolm Gladwell's book, The Tipping Point, explored these issues in a captivating way, and there is a growing academic literature on the power of networks for understanding what Urban and Koh call the "inner workings of corporations as small-scale (or even large-scale societies)."16

\footnotetext{
${ }^{14}$ Louis Galambos and Jane Eliot Sewell, Networks of Innovation: Vaccine Development at Merck, Sharp \& Dohme and Mulford, 1895-1995 (New York and Cambridge: Cambridge University Press, 1995); and Louis Galambos and Jeffrey L. Sturchio, "Pharmaceutical firms and the transition to biotechnology: a study in strategic innovation," Business History Review 72 (Summer 1998): 250-278.

15 This is the argument of Mark Granovetter's classic paper, "The strength of weak ties," American Sociological Review 78, no. 6 (May 1973): 1360-1380; see also his subsequent paper, "The strength of weak ties: a network theory revisited," Sociological Theory 1 (1983): 201-233.

16 Urban and Koh, "Ethnographic research on modern business corporations," (note 8 above). See also Malcolm Gladwell, The Tipping Point: How Little Things
} 
How then does the culture of these corporate societies have an impact on the work they accomplish, the commitment and cooperation of the professionals who drive those accomplishments, and the effectiveness and efficiency of the internal and external networks that enable companies to innovate and operate efficiently ${ }^{17}$

We can only adumbrate these ideas in this essay, so let's focus on the role of the CEO as Kulturträger. Because of his or her central role in providing vision and leadership for the organization, the CEO plays a critical role in articulating and promulgating key cultural values for people at all levels of the modern corporation. This is just one element of the complex role of the modern CEO, who has to find the right balance among innovation, control and efficiency to ensure optimum and sustainable outcomes for the diverse shareholders and stakeholders that every corporation has. ${ }^{18}$

An intriguing example of how successive CEOs used narrative and myth about organizational values and strengths to focus the efforts of their corporations comes from Hewlett-Packard, where John Young used the theme of quality from 1980-1992 to address the challenges that HP faced during his tenure. He was succeeded by Lewis Platt, who focused on re-engineering from 1992-1999, and then Carly Fiorina, whose narrative during her tempestuous tenure from 1999-2005 centered on reinvention. These overarching themes enabled Young, Platt and Fiorina to rally the entire organization around strategic visions tailored for the particular competitive and cultural challenges faced over a 25-year, transitional period. It would be interesting to contrast this sharply-

Can Make a Big Difference (Boston, Massachusetts: Little, Brown \& Co., 2000); Robert Cross, Andrew Parker, Lisa Sasson, eds., Networks in the Knowledge Economy (New York and Oxford: Oxford University Press, 2003); Robert Cross and Andrew Parker, The Hidden Power of Social Networks: Understanding How Work Really Gets Done in Organizations (Boston, Massachusetts: Harvard Business Review Press, 2004); and the work of Sinan Aral at New York University, e.g., David Lazer, Alex Pentland, Lada Adamic, Sinan Aral et al., "Life in the network: the coming age of computational social science," Science 323 (6 February 2009): 721-723; and Aral and Dylan Walker, "Identifying influential and susceptible members of social networks," Science 337 (20 July 2012): 337341.

${ }^{17}$ We have found Ken Lipartito's essay on "Culture and the practice of business history," Business and Economic History 24, no. 2 (Winter 1995): 1-41, helpful in this regard. Also, a recent article in the Harvard Business Review posits an important role for "sensemaking" in applying the human sciences to help business organizations understand how to navigate unfamiliar social or cultural contexts and challenges. This seems close to the spirit of how we see the role of professionals and networks in creating and adapting corporate culture to help businesses achieve their objectives; see Christian Madsbjerg and Mikkel B. Rasmussen, "An anthropologist walks into a bar...." Harvard Business Review, March 2014, reprint R1430F.

18 Louis Galambos, “What have CEOs been doing?" Journal of Economic History 48, no. 2 (June 1988): 243-258; and Galambos, "The authority and responsibility of the chief executive officer: shifting patterns in large US enterprises in the twentieth century," Industrial and Corporate Change 4, no. 1 (1995): 187-203. 
focused vision with the reality that people experienced at different levels within HP at this time. ${ }^{19}$ There are many other examples of this use of visions and values to reinforce cultural direction within modern corporations - one other case of interest was how Raymond V. Gilmartin renewed George W. Merck's famous apothegm that "medicine is for the patients, not the profits" (from a 1950 speech to the Medical College of Virginia) early in his tenure as CEO at Merck \& Co., Inc., and made it a central element of his articulation of the company's overarching values.

Finally, we agree with Ronald Kroeze and Sjoerd Keulen that "leading a modern corporation is history in practice." Drawing on their study of the uses of narrative by leaders at several Dutch corporations, they conclude that history is an important source of the traditions and symbols needed for communication; for strengthening the shared understanding of the institution's identity; and for connecting that past with the present and future of the corporation. ${ }^{20}$ As we've tried to show in this essay, we also think there are important lessons from business history about the impact of new professional roles in the corporation, about the "hidden life" of social networks, and about the role of corporate culture in reinforcing the daily practices of corporate life. We hope we've shown enough congruence between these historical perspectives and the approaches that business anthropologists have taken in their ethnographic research on the corporation to encourage our readers to undertake some cross-disciplinary explorations of their own.

\section{How Business Methods Change: The Cases of Salesmanship and Forecasting}

Walter Friedman, Director of the Business History Initiative, Harvard Business School

I became interested in studying the history of business while getting my doctorate at Columbia in the 1990s. After a class on the 1920s, I grew particularly curious about how well the image of the salesman depicted in Sinclair Lewis's novel Babbitt (1922) corresponded to reality. But I had little understanding of the broader transformations that were occurring

\footnotetext{
19 See Sotirios Paroutis, Max McKeown and Simon Collinson, "Building castles from sand: unlocking CEO mythopoetical behaviour in Hewlett Packard from 1978 to 2005," Business History 55, no. 7 (2013): 1200-1227.

20 Ronald Kroeze and Sjoerd Keulen, "Leading a multinational is history in practice: the use of invented traditions and narratives at AkzoNobel, Shell, Philips and ABN AMRO," Business History 55, no. 8 (2013): 1265-1287.
} 
in business in that period. So, like many history students, I turned to the work of Alfred D. Chandler Jr. Starting in the 1960s, Chandler had developed a series of landmark books, the most famous of which was Visible Hand: The Managerial Revolution in American Business (1977). That book provided the best general overview of the evolution of business in the United States - and still does.

I was particularly struck by Chandler's methodology. Like many historians, Chandler believed in deep primary research, making use of annual reports, correspondence, the diaries of businesspeople, industry trade journals, advertisements, board meeting minutes, company by-laws, reports from the Bureau of Corporations, and anything else he could find. But his work had other distinguishing characteristics. It was driven by big research questions: Why did large companies emerge in certain industries and not others? Why did companies differ in their organizational structure? Why did large companies emerge in some countries and not others?

In answering these questions, Chandler believed in taking a comparative approach, looking at how entrepreneurs, companies, or countries were similar or different from one another. Chandler was also interested in studying business functions (management, production, and distribution, for instance) and how they evolved over time. This emphasis arose in part from studying with sociologist Talcott Parsons. Parsons convinced him to think about society as a structure of interrelated parts - and to think about institutions and their evolution over time. Were they like organs in the human body? What do they do? How did they grow and change? He was also influenced by the work of economist Joseph Schumpeter, who emphasized the role of entrepreneurs in the "creative destruction" inherent to capitalism. Entrepreneurial activity, Schumpeter argued, created "new combinations" that brought about new products, processes, or markets and disrupted old methods of doing business. ${ }^{21}$

Chandler's book Strategy and Structure (1962), for example, examined the question of why large firms developed different organizational structures. Why did some adopt a multidivisional structure and others did not? What did the strategy of the firm have to do with its structure? In the book, Chandler profiled the evolution of management at four companies (DuPont, General Motors, Standard Oil, and Sears). The British economist Barry Supple remarked on the comparative aspect of the book. "Strategy and Structure was novel because, as Chandler pointed out, it concentrated on a comparison of the ways in which different enterprises carried out the same activity administration - rather than studying how a single firm undertook all its

21 On Schumpeter, see the biography by Chandler's long-time colleague, Thomas K. McCraw's Prophet of Innovation: Joseph Schumpeter and Creative Destruction (Cambridge, Mass.: Harvard University Press, 2007). 
functions." 22 As a trained historian, Chandler argued for the necessity of collecting large amounts of empirical facts about the operation of firms and then using these facts to formulate conceptual conclusions. "Each case study [in this book] presents the events from the point of view of the busy men responsible for the destiny of their enterprise," Chandler wrote. "Only by showing these executives as they handled what appeared to them to be unique problems and issues can the process of innovation and change be meaningfully presented." 23

After Columbia I was lucky enough to go to Harvard Business School on a postdoctoral fellowship and to work with Chandler. The book I eventually produced, growing out of my dissertation on salesmen, was deeply influenced by Chandler's approach. For one thing, it explored the evolution of an economic function (selling) over time. Birth of a Salesman: The Transformation of Selling in America (Harvard, 2004) was a history of the rise of sales management in the late nineteenth century and the early twentieth. How did the U.S. move from having an economy populated by peddlers and traveling salesmen to one with highly managed salespeople at places like National Cash Register, Burroughs, Chevrolet, and IBM? Why did methods of selling change over time?

I looked at all sorts of documents, including sales scripts from Singer Sewing Machine, Encyclopedia Britannica, and other firms. I located diaries of nineteenth-century salesmen and memoirs of commercial travelers. I included a detailed study of National Cash Register, a pioneer of systematic approaches to sales management. My chapter on NCR was written largely through an analysis of its internal company magazine (the NCR), court cases involving the company, and published recollections of former employees. Sometimes, in the book, ephemeral items proved highly important. I took an interest in joke-books written for traveling salesmen to read on trains. At first these seemed relatively marginal to my subject. But the more of them I saw, the more I realized that they were essential to the traveling drummer's repertoire. How else could a stranger, in the late nineteenth century, make a connection with an unfamiliar general storekeeper? A good joke - about a mother-in-law or other third party - might help break the ice.

I tried to be comparative in my approach. I analyzed how ideas about salesmanship varied in different types of business. How did the sale of books and perfume, sold door to door, differ from the sale of large computer systems? What industries developed sales forces and which did not? Which industries relied more on advertising?

I also returned to my original cultural interest in Babbitt, but tried

22 Barry Supple, "Scale and Scope: Alfred Chandler and the Dynamics of Industrial Capitalism," Economic History Review XLIV 3 (1991): 500-514. ${ }^{23}$ Alfred D. Chandler, Strategy and Structure: Chapters in the History of the American Industrial Enterprise (Cambridge, Mass: MIT Press, 1962; edition used, 1995), p. 7. 
to relate it to broader trends. Why did the image of the salesman change so much over time? In Yankee folktales, the figure of the salesman was that of a powerful stranger, who would arrive in town unannounced and trick people into buying things. By the early twentieth century, in Babbitt, the salesman was no stranger at all, but rather a town booster and archetypal American. However, he was also weaker, a follower of news slogans and advertisements. After World War II, with the character of Willy Loman in Arthur Miller's Death of a Salesman, the salesman became a tragic figure, as disposable as the products he sold. In many ways, the broad changes in the realities of business - the demise of itinerant peddlers, the growth of national sales networks, and the rise of sales management-resonated with cultural representations. Selling became more central to the American economy, while salesmen became more heavily managed and more replaceable.

While I pursued my own interests, Chandler's work - functional, comparative, and highly detailed - was an important guide. The same was true for my second book. Fortune Tellers: The Story of America's First Economic Forecasters (Princeton, 2014), was also about the evolution of an economic function - in this case forecasting - over time. It looked at the first generation of forecasters who started their predictions in the early twentieth century and continued on, for the most part, until the Great Depression.

In researching this book, I also looked at a range of primary sources. These included correspondence (sometimes from angry subscribers), get-rich-quick pamphlets, bulletins from the National Bureau of Economic Research and the Econometric Society, and early forecasting charts - some of which were beautifully done prints with vibrant colors. The main sources for the book were the weekly forecasting newsletters themselves - including the Babson Report, the Brookmire Forecaster, and the Harvard Economic Service's Weekly Letter. I also researched government archives, both in the U.S. and abroad, as forecasting became tied to public policy.

I tried to shape the book around central research questions: How did the forecasting field, once based on intuition and inside knowledge, become one with highly technical macro-economic models? What made one forecaster more successful than another (especially given the fact that there was little data about which forecasters were accurate)? What was the relationship of forecasting and meteorology, another science developing in this period? When did the U.S. government become interested in economic forecasting and why?

I also tried to make the book comparative in nature, especially in terms of understanding how forecasts were produced. One forecaster, Roger Babson, believed that a careful study of past economic patterns, revealed in numeric data series (an amalgam of output, prices, and crop yields) would repeat endlessly into the future. Another, Warren Persons, 
of Harvard, argued that the future could best be understood by finding analogous instances in the past. Was 1921 most like 1884? Or 1893? Finding the right analogy would help uncover the future. Still a third forecaster, Irving Fisher, thought that past trends and analogous events were useless in understanding the future. He instead developed a mathematical model that aimed to track when credit flows were healthy and when they were overextended. He also tried to understand what caused economic growth: Patents? Managerial innovation? Financial reform? Each forecaster I profiled in the book introduced a different way to think about the economic future - and each forecasting method has had its own legacy, down to today, a time when forecasts are omnipresent.

One of the reasons Chandler's work has proven so enduring and inspirational stems from the fact that his approach was multidisciplinary. He gained a lot through his reading of sociology and of economics. These disciplines helped him to conceptualize large economic institutions and to understand the dynamism of capitalist economies. In turn, his work has found a wide-ranging audience among historians, sociologists, management scholars, and economists. Capitalism and business enterprise - the focus of his work - are such complex and multifaceted subjects, it is not surprising that different perspectives provide insightful approaches. Hence, I am optimistic that there is much to be learned from collaboration between anthropologists and historians interested in business.

\section{Is Business Anthropology Useful for Business Historians? Potential Highways and Dead-ends}

Eric Godelier, Professor of Management, Business History and Social Sciences, École Polytechnique, France

Educated as an economist, although surrounded on all sides from when I was very young by anthropology, graduated as a historian, and now teaching multicultural management and corporate culture, I have always had both my research and my professional career nourished by multidisciplinarity. For this reason, it is a great pleasure to be able to contribute to this special issue of the $J B A$, although it is clearly impossible to propose here a complete and systematic synthesis of the various relations that might be built between business history and business anthropology. Nevertheless, I will continue since I have been invited to write some informal remarks for readers of the $J B A$ - to make some suggestions for future and possible fruitful exchanges between our 
disciplines. Such reflection could lead to discussing the possibility - and the opportunity - that an ethnographical approach might have in creating historical knowledge, and especially, 'workable' know-how. In this respect, it seems important to separate methodological issues from conceptual debates.

\section{The usefulness of ethnography for modern business history... and vice and versa}

The field of business history is broad and varied. Depending on the topics, periods and objects studied by business historians, potential contacts with business ethnography could be very helpful, or alternatively lead to dead-ends. In France since the 1980s, many business historians have been innovating by doing fieldwork and developing a kind of methodology very similar to those used by (anthropological) ethnographers. In his book Organizational Ethnography, ${ }^{24}$ Daniel Neyland presented a set of instructions, or guide, for how to become an organizational ethnographer. In many respects, the 'ten sensibilities' he described (for instance, location and access, field relations, questions of knowledge, observing and participating, and so on) could be used directly by business historians involved in the history of recent organizations, since these days more and more business historians are requested to contribute, in one way or another, to official celebrations - much of the time as providers of facts for legal debates, or of official corporate culture assessments and values. Moreover, some business historians have been designing action research programmes, in order to be able to enter organizations or corporations and to move undercover therein. Indeed, in many respects, the problems they face in being accepted inside organizations are very similar to those encountered by anthropologists. How can they move beyond official structures and formal manifestations of such structures to arrive at an understanding of people's everyday behaviour? Frequently, business historians have to face the problem of evaluating their personal and professional relationship with an organization's leaders and values. Therefore, using the experience and methodological knowledge accumulated by anthropologist ethnographers could be helpful.

By suggesting that all social scientists should go behind the screen, anthropology - and its methodological branch, ethnography - has strongly pushed for an in-depth research process. Classical ethnography demands a long stay in the field. Through daily observations of individual or collective behaviour, one should get as close as possible to people's intimacy, their values, and culture. In the end, this should also be the ultimate target of business historians: to discover the actual elements,

24 Daniel Neyland, Organizational Ethnography. Sage, London, 2008. 
actors, and structures present and to get as close as possible to history and historical 'truth'.

Last but not least, from a business historian's perspective, ethnography could be helpful for the design and maintenance of an intellectual and methodological distance between observer and observed. Here Georges Devereux has frequently explained the influence of psychological problems on anthropology. ${ }^{25}$ Moreover, ethnography could prevent business historians from falling into ethnocentrism. New research topics in business history - like technology transfers between various countries or corporations, sending top managers and leaders abroad to work, corporate globalization - could benefit from the experiences of ethnography, which raises, for instance, the question of indigenous management and the technical or intellectual tools needed to analyse it. ${ }^{26}$

At the same time, however, I think that ethnography could also benefit by learning from history and business historians. In France, anthropology and history have been engaged in more or less continuous discussion, and occasional arguments, for several decades. In the 1960s, Claude Lévi-Strauss and Ferdinand Braudel entered into a famous polemic on the importance of history for anthropologists. ${ }^{27}$ Lévi-Strauss's conclusion was that history is needed because ethnography is dealing with historical objects, but that its use should be limited. For his part, Braudel insisted that anthropologists study history in depth in order to put their field research and scientific object of enquiry into context. Once they become interested in business and corporations, therefore, business anthropologists should in one way or another take time for a precise consideration of history. Archives, oral interviews with informants, and global history all have to be mobilized as complementary sources of information, evidence, and proof. Since the early 2000s, more and more business historians have developed a sophisticated approach of this nature to the study of oral sources and their importance in business history. In so doing, they are trying to improve the status of oral history in business history, as well as in history in general. ${ }^{28}$

This short, though obviously incomplete, set of methodological issues could, I think, be a first cornerstone of a future and fruitful dialogue

25 See, for instance, G. Spindler (ed.), The Making of Psychological Anthropology. Berkeley: University of California Press, 1978.

${ }^{26}$ See, for instance, D. Marsden, 'Indigeneous management and the management of indigeneous knowledge'. In S. Wright (ed.), Anthropology of Organizations. London: Routledge, 1994 ( $2^{\text {nd }}$ edition 2002), p. 41-55.

27 C. Lévi-Strauss, 'L'anthropologie sociale devant l'histoire'. Annales ESC, XV, 1960, p. 625-37.

28 F. Descamps, L'historien, l'archiviste et le magnétophone. De la constitution de la source orale à son exploitation. Paris: Comité pour l'histoire économique et financière de la France, 2001. 
between business anthropology, ethnography, and business history especially if they engage in new exchanges of concepts.

\section{Concepts and critiques}

In my opinion, several concepts could be imported from anthropology and used by business historians. Amongst them, I would like to select three of what I consider to be the most important: institutions, culture, and myths.

First, institutions. When working on organizations, business historians need intellectual tools to describe and define their objects of study: for instance, small and medium enterprises, large corporations, associations, or public bodies. It is very difficult to find a single and precise definition of enterprise and entrepreneurship - either in history, or in economics or management sciences. Each discipline tends to emphasize just one aspect of the enterprise: like, for instance, organization structures, material or informal resources, information, influence on market regulation, decision processes, leadership, and so on. Any one of them is able to provide something more synthetic, and even a single definition of enterprise and corporation.

The concept of institution here could prove very helpful, and yet business historians are not very comfortable about using it. For instance, in the introduction to Giants of Enterprise, R. Teldow underlines the fact that:

"no theory of institutions which does not take account of talent, genius, idiosyncracy, and, at times, idiocy of the individual leader can explain how America came to do best what it does best. [...] This book is thus the story of individuals and institutions. But the individuals take center stage, while the institutions, both public and private, provide the background" (p. 3).

Again, Teldow underlined the fact that there was 'no typical American business executive' - a statement which could be understood to imply that there were no social regularities. Does it mean that energy and ambition are stronger in some parts of the population than in others? If this assumption is true, it becomes impossible to conclude that there is no social or cultural regulation intervening in the social selection process. ${ }^{29}$ If this process is purely hazardous, it is impossible to explain the obvious differences. We need a more complex model to describe and analyse the origin and path of an entrepreneur's social and economic success.

29 Of course, it is also possible to use racist theories, which have tried from a very long time ago to explain social inequalities and differences by the concept of socalled 'natural differences'. 
One possible solution can be found in Mary Douglas's work on norms, values and institutions. In her famous book How Institutions Think, ${ }^{30}$ she explains how institutions frame people's representations, values, and behaviour through a process of selection and institutionalization of cultural and symbolic items. This leads to a naturalization of forms of representations used by community members. She described how, at some point, the metaphors and myths used get solidified, accepted, and reinforced by most people in the community. At this point, it becomes hard for any individual to escape the patterns and categories of thought defined by these institutions. This is the sense of Douglas's assertion that 'institutions think'. Within these categories and agendas, individuals may even make rational benefit cost calculations amongst alternatives without considering the categories themselves. This powerful intellectual frame is becoming more and more widespread amongst French business historians.

Second, culture. Another concept originally stemming from anthropology is that of 'culture'. Nowadays, more and more business historians in France - indeed, around the world - are in some way dealing with, or even focusing on, culture. ${ }^{31}$ This is also an accepted 'truth' in organization studies, ${ }^{32}$ where more and more publications are presenting historical research on worker communities, corporate culture, leadership values, multicultural management, and so on. Since the mid-1980s, many have been influenced by Geert Hoftede's research on values and cultural hierarchies, ${ }^{33}$ while others make use of Edward T. Hall's work on 'nonverbal' communication, language, and culture. ${ }^{34}$ Nevertheless, since publication of Culture: A Critical Review of Concepts and Definitions by A. L. Kroeber and Clyde Kluckhohn, ${ }^{35}$ one needs to be more careful with this concept. Many definitions used by business historians are still imprinted by essentialism and western ethnocentrism. A closer dialogue with anthropology would enable them to develop a more rigorous approach to the study of culture in business and organizational studies, the history of corporations, multicultural management, and the globalization of management practices and tools. ${ }^{36}$

\footnotetext{
30 Mary Douglas, How Institutions Think. Syracuse University Press, 1986.

31 One could have a look at the Business History Conference (BHC) online website, or at its meetings. See for instance my book on corporate culture: $L a$ culture d'entreprise. Paris: LaDécouverte, 2006.

32 S. Wright (1994), 'Culture in Anthropology and Organizational Studies'. In her edited Anthropology of Organizations. London \& New York: Routledge, 2nd Edition, 2002, pp. 1-31.

33 Geert Hofstede, Culture's Consequences: International Differences in WorkRelated Values. Beverly Hills CA: Sage Publications, 1980.

34 For instance, E. T. Hall, The Silent Language. New York: Anchor Books, 1959; or The Hidden Dimension. New York: Anchor Books, 1966.

35 A. L. Kroeber and Clyde Kluckhohn, Culture: A Critical Review of Concepts and Definitions. New York: Vintage Books, 1952.

36 For instance, see the open Website: mtpf.mlab-
} 
This brings me to my last example of possible exchanges between anthropology and business history: the concept of myth. Official biographies of famous entrepreneurs often emphasise the importance of loneliness, poverty, and strong spirit of the young creator. These elements are symbolically summarized by the 'garage', which allowed the business innovator to start up his activity. ${ }^{37}$ In the United-States, Bill Hewlett and Dave Packard, Bill Gates and numerous others are supposed to have used the family backyard for their first step towards success and wealth. They are often presented as former students who left college or university before graduating, or, sometimes, after being sent down because of bad results or inappropriate behaviour. For instance, Andrew Carnegie, a Scottish immigrant from Dunfermline, was recruited as a simple telegraphist, before becoming a tycoon in the steel industry. Henry Ford, left school at the age of 16 and created his industrial empire. In France also, it is possible to find similar cases. Louis Renault failed to enter the École Centrale, a famous French school for engineers, but was later regarded as a genius in mechanics. Charles Pathé was a fairground entertainer who became a famous millionaire in 1913. To this list, one might also add Coco Chanel.

Most of these people have become business heroes, both in public opinion and in the world of management. How could this have happened? How does someone with officially few or no technical, commercial, financial, or managerial knowledge become a successful entrepreneur and managerial hero? Obviously the world of business creates its own myths and heroes. Business historians could use the frame of historian P. Veyne, ${ }^{38}$ and of anthropologist Lévi-Strauss, ${ }^{39}$ to understand what managerial myths reveal about entrepreneurship - whether among individuals or communities - and, in the process, what they hide from public opinion and society at large. For instance, Steve Jobs or Bill Gates presents himself as a mythic person: a young creator, 'self-taught man' in the computer industry, and adventurer. Very often, as I said, creators represent themselves, and are represented by others, as bad students, reluctant to follow the rules of education institutions, and therefore rejected by the official system. ${ }^{40}$ The implicit messages in such myths are

innovation.net/fr/introduction.html

37 For instance, the Palo Alto garage where Hewlett and Packard started its business in 1939 with a $\$ 538$ investment was, in 1987 , designated as a California State Historical Landmark.

38 Did the Greeks Believe Their Myths? An Essay on the Constitutive Imagination. Chicago: University of Chicago Press, 1988.

${ }^{39}$ C. Lévi-Strauss and D. Eribon, De près et de loin. Paris: Odile Jacob, 1988. 40 In November 2006, Steve Balmers came to the Polytechnique where he presented himself 'as a student who failed to graduate'. Nevertheless, later in his speech, he mentioned the fact that his father had supported him financially during his studies in Harvard, and that he had passed all the credits of the Stanford MBA except two. Instead of finishing these two courses, however, he decided to help Bill Gates to create Microsoft. As a result, therefore, he did not officially graduate. 
clear: social promotion is based on personal merit and democratic criteria. In a way, social rules and institutions have no negative influence on the new businessman. If someone is smart and dynamic enough, he (or she) will be promoted.

A second aspect of myth that might be considered by business historians is mythic innovation. With the Macintosh, Apple became the first computer corporation to develop a commercially successful PC with a graphical user interface. Once again, it is possible to find some elements of the myth: innovation opposed to inertia and business conservatism (symbolized by IBM); or the dwarf surpassing the giant (Rank Xerox or IBM). Obviously, using an anthropological framework here could be very useful for business historians.

And yet, it is important to define the concept of myth and what it means. ${ }^{41}$ One definition might present a myth as a particular kind of narrative. A good example of this is that of the Greek gods, which provides a model for the origins of mankind and the natural world. Nevertheless, myths are not tales as such, because they tend not to be pure invention. And yet they are not lies, either, because they are also partly true. Often, within the myths, actual facts are mixed with things - I use this word intentionally - but in an obviously unrealistic way. But, even if they speak about the past and try to explain it, myths cannot be said to be history, for they are but barely based on precise and proven facts (dates, testimonies, objective sources). Myths also have no fixed length in either time or space. Talking about the past, they offer a picture of a perfect world, seen as a universal and original matrix. Last, even if they present 'holes' improbabilities or dead-ends in the panorama - myths are regarded as truths by members of a specific community. Therefore, community members believe in a myth, not through an explanatory process, but mainly through adherence to it. Thus, only aliens would be able to observe what they would then refer to as 'imperfections', 'irrationalities', or 'superstitions'.

But the most difficult thing of all is that myths cannot be reduced to a static or pure old-fashioned form of folklore. They produce knowledge and actions which are able to evolve. This leads us to ask what the main characteristics of myths might be. Lévi-Strauss underlines the function of structuration: myths are used to explain some parts of reality and to hide others. By doing this, they structure the categories of the human mind. In this respect, G. Dumezil, too, showed that myths are not totally linked to reality and social organization. It is possible to see them as a symbolic model of the actual. Lastly, therefore, we might say that myths have two functions: they provide a kind of coherent structure of facts and

\footnotetext{
41 There are numerous definitions and debates in social anthropology, as well as in sociology and linguistics, about myths. My definition here is based on what is commonly shared among social scientists. See P. Smith, 'Mythe: approche ethnosociologique'. Encyclopaedia Universalis, 2007.
} 
explanations of the world; and they are useful to help communication within a group. Myths thus have an origin: they are diffused and institutionalized. ${ }^{42}$

Nowadays, these representations and myths are clearly having an influence on corporate history researchers. For instance, it is interesting to read Alfred Chandler's enormous work on management capabilities and communities within this analytical frame. In a way, Strategy and Structure: the Visible Hand and Scale and Scope sometimes present leaders and managers as extraordinary individuals, at others as lonesome innovators. But stories are not myths, and through their work business historians could explore the roots of several business myths. In this way they could develop a positive critique of the concept and contribute to a better understanding of business myths. Indeed, some scholars in management studies have already made a really interesting contribution on such topics. ${ }^{43}$

In conclusion, let me say that the aim of this short opinion piece was not to make a conclusive contribution to the potential relationship between anthropology and business, but to suggest ways in which these two disciplines might in the future share some common objects of interest, and so develop fruitful intellectual exchanges. The huge variety of topics, methodologies, and intellectual tools developed by business historians around the world could supply such exchanges with renewed perspectives. As mentioned earlier, in 2011, French business historians published an online book on the history of French management models and thought between the eighteenth and $21^{\text {st }}$ centuries. One aim of this project was to design a kind of genealogy and history of social and political networks, the sources and trajectories of management techniques, models, and representations in France and around the world. Obviously some common elements could represent a starting point for new discussions between business historians and business anthropology and ethnography.

\footnotetext{
42 This section was inspired by Paul Veyne, Les Grecs ont-ils cru à leur mythes? Paris: Seuil, coll. « Points », 2nd Edition, 1992. (Translated into English in 1988 by Paula Wissing: Did the Greeks Believe in Their Myths? An Essay on the Constitutive Imagination. Chicago: Chicago University Press, 1988.)

43 The author would like to thank Jim March for confirmation that the texts on management myths were only published in French: J. March, 'Les mythes du management', Les Annales de l'École de Paris, vol. V, 1999, pp. 387-394; J. March, T. Weil, Le leadership dans les organisation. Paris: Presses de l'EMP, 2003.
} 


\section{History and the Anthropology of Firms: A Legal Perspective}

Gwendolyn Gordon, Assistant Professor of Legal Studies and Business Ethics, and

Eric W. Orts, Guardsmark Professor of Legal Studies and Business Ethics and Professor of Management, both at the Wharton School of the University of Pennsylvania

Many years ago, social theorists noted the wary, dawning recognition on the part of both historians and anthropologists of the possibility that "history itself was inherently cultural, and culture, inherently historical" (Dirks, Eley, and Ortner, 1994:6). There was some hesitation at the start of anthropology's version of a "historic turn" (McDonald 1996), a shift in the field that, as Sherry Ortner observed, might have been characterized equally validly as "a move from structures and systems to persons and practices" as the more obvious "shift from static, synchronic analyses to diachronic, processual ones” (1994:402). Anthropologists' wariness of the unruly prodigal concept of "culture" was also encouraged by this historical shift. An historical perspective raises questions about the durability, contingency, and cohesiveness of "culture" (Dirks et al 1994). With the shift to historicity occurring, as it did, simultaneously with a number of other challenges and changes to the discipline (perhaps most notably the insistent incursions upon anthropological theory of postmodernist critiques), some measure of disciplinary discomfiture was to be expected. Much of this self-conscious reassessment persists and is apparent in anthropology's intermittent disciplinary re-positioning and boundary-policing in relation to the discipline of history, a theme which has been present ever since Maitland's claim that "anthropology must become history or be nothing" (Comaroff 1982:142, paraphrasing Maitland 1936: 249). An equally present anxiety appears in "studying up" to gain access to and represent elites, such as the "bosses" of business firms, who often tend to be the focus of the work of business anthropologists (e.g., Carrier 2013; see also Nader 1972, Gusterson 1997). The combination of these two persistent forms of disciplinary discomfort contributes to a uniquely generative ground for a reconsideration of the potential for methodological cross-fertilization between anthropology and history with respect to business enterprise.

When anthropologists get uncomfortable, it seems, they get introspective. This is as true for the growing importance of anthropological ways of looking at business today as it was for the earlier engagement of anthropologists with historiography. As historiography was becoming an established, valued tool for anthropologists, anthropologists debated the proper relationship between the two disciplines. For Jean and John Comaroff, using history involved reading 
archival records ethnographically, on the theory that "once the motives, intentions, and imaginings of persons living or dead are allowed to speak from the historical record, it becomes impossible to see them as mere reflections of monolithic cultural structures or social forces" (1991:10). This kind of history was at odds with a history that made fine distinctions between "reality" and "representation," as well as with the persistent popular division of representation into realism (factual, documentary) and rhetoric (evaluative, interpretive, expressive). If forms of representation were "part of culture and consciousness," then historical consciousness could not be confined to "one expressive mode" (1991:35). Meanwhile, Ortner and others argued that the key theoretical difficulty giving rise to the day's anthropological insecurities was the seeming inability to account for several interrelated features of social life: (1) the way that society, while "a human product," seemed also to bind the scope of human action and thought; (2) the way that society (as an earlier anthropology had emphasized) was "an objective reality" that was nonetheless somehow also constructed; and (3) the way that human beings, in one view the authors of society, were also and at the same time "a social product" (1994:402, quoting Berger and Luckmann 1967:61). An uncritical anthropological accounting of history alone - history as a preface - was no solution to this conceptual difficulty. The efforts of Ortner, Dirks, and others promoted a variety of historical anthropology characterized by "a kind of dislodging of a whole series of assumptions about what culture is and how it works" (Dirks et al 1994:6; see also Spear 1994).

Now, however, the "depthless subject with no sense of history" lamented by Dirks et al (1994:14) has been revealed anew as problematic. Today, in the wake of a seemingly endless tide of corporate and financial perfidy and disaster, business institutions (and the people acting within them) have tended to become a flat subject for too many anthropologists. We, of course, exclude the editors, contributors, and readers of the Journal of Business Anthropology, whose work has valiantly countered this trend within mainstream anthropology.

In 2009, Marina Welker described two dominant analytics in the critical anthropological literature of business entities: a "bad apples" approach that focused on individuals - CEOs or financiers as supermen and/or psychopaths - and an institutional approach that diminished the importance of individual agency, instead pointing to larger forces in examining the negative social effects of firms. The dominance of these two approaches meant that even when the individuals involved with the management and governance of corporations were imagined as "coherent political actors" (Dirks et al 1994:14), they were either inflated into the bad actors whose personalities overwhelm the businesses in which they operate or deflated into actors whose political and moral preferences were necessarily ineffective in the face of the deterministic force of shareholder value (Welker 2009:148). The analysis of the innards of the 
business firm becomes, in either of these views, nursery rhyme simple: if the firm is bad, and you have directive agency within it, you must be bad. If the firm is bad, and you are good, you must lack the agentive power to change its behavior. It becomes very difficult to imagine the firm otherwise.

Here is where the early debates regarding to the importance of individual agents in understanding the persistency and contingency of cultural life gain new legs. The historical anthropologies developed by Comaroff and Comaroff $(1991,1992)$, Ortner (1989), Moore (1987), and others who have followed them hold aloft at once the "real" and the "constructed" nature of social life. They demonstrate that an examination of the quotidian practices of seemingly seamless, timeless entities will be one way to work toward their demystification, their disaggregation - and their historicization (cf. Orts forthcoming). We believe that the same will be true in particular of anthropological investigations of business firms in their historical context, which should include an appreciation of their intricate legal structures and complex evolution.

Teemu Ruskola (2014) advances a similar point in relation to comparative legal research on the business corporation, emphasizing the necessity of efforts to render and keep visible the historical contingency and the cultural specificity of liberal theories of enterprise organization. The stakes are great. The Citizens United case, for example, might be considered a paradigmatic result of a "just-so" reading of the idea of business firms as legal persons and the possibilities of corporate citizenship (Sepinwall 2012). On a close analysis, however, the case reveals significant theoretical questions about how we conceive of the social construction of business firms and the legal rules that govern and constrain them (Orts 2013: 239-50). Anthropological research on business might be seen to play a similar role, contextualizing and denaturalizing assumptions implicit in liberal theory. Greater attention to comparisons and historical context will likely bring more critical attention to the way we - anthropologists, historians, legal scholars, and the public - imagine and naturalize business firms.

The paucity of counter-narratives to entrenched economic theories of the firm has limited a number of disciplines (Orts 2013: ix-xviii). Legal scholars have worked to develop legally grounded theories of the corporate form, its "personality," and its place in society (Ho 2012; Iwai 1999; Millon 1990, 2001; Orts 1998, 2013; Ruskola 2000, 2005, 2014). Anthropologists have also begun to work to develop alternative theories (see, e.g., Aiello and Brooks 2011, Dolan et al 2011, Foster 2010, Gordon forthcoming; see also Urban and Koh 2013). Part of the continuing task of theorizing contemporary firms involves a descriptive analysis of how social and ethical commitments become drawn and redrawn by the various participants in business firms, including owners such as shareholders and creditors, managers and other employees, and other 
constituent groups (Gordon forthcoming; Orts 2013). Historically and legally informed ethnographic research is particularly well-suited to make contributions to this field.

To be sure, the business firm - or more specifically, and more usually, the multinational corporation - has been commonly cast as a type of acceptable anthropological "other." Despite the importance of business firms and corporations in our daily lives, and despite their powerful presence in ethnographic explorations of the effects of global capitalism and despite, too, decades of real interest of ethnographers in the effects of corporations (e.g., Fortun 2001, Kirsch 2006, Nash 1989, Sawyer 2004), particularly in Japan (e.g., Allison 1994, Clark 1979, Moeran 1996, Rohlen 1974) - there have nevertheless been very few anthropological views on these organizations that move beyond an exegesis of their harmful effects. As Welker et al. note,

We have yet to see the emergence of a sustained line of scholarship and inquiry that would extend to the corporation the same critical weight or significance accorded the nation-state.... To date, one cannot discern a coherent set of research questions or competing schools of thought characterizing the anthropology of corporations. (2011:s4-s5)

Anthropology has lacked, in other words, both a depth and a diversity of approaches to the question of corporate and other business forms. Welker (n.d.) has analogized the difficulties in the anthropological study of the corporation to the difficulty that Abrams noted in scholarship of the nation-state. Scholars, while ostensibly disaggregating the state in theory, found it necessary in practice to act as if "the state" were a bounded, agentive, solid entity (Abrams 1988). Welker likens this to current characterizations of the corporation: failing to demystify it, anthropologists have tended to represent it as smooth, all-powerful, and unknowable (n.d.:7-10; Cf. Ballard and Banks 2003:293-4, Subramanian 2010:480). Unlike the anthropology of the nation-state, however, the anthropology of corporations and other business firms has remained ahistorical and under-theorized.

Yet anthropologists are particularly well-suited to destabilize the paradigmatic conception of business firms as all powerful, all encompassing, and an overwhelming force - a notion that Welker et al. conjecture is connected to "a parochial view that derives from the peculiar legal career of corporations in the United States" (2011: s5). The suggestion of these and other anthropologists of large-scale elites for countering the aggrandizing effect of more abstracted impressions of business firms is underlain by the same methodological insight reached by Ruskola (2014) - the understanding that careful attention to the quotidian particularities of business firms can be central in historicizing them (see e.g. Aiello and Brooks 2011, Ehrenriech 2010, Miyazaki and 
Riles 2005). The idea is to "shift away from default conceptualizations of corporations as solid, unified, self-knowing, and self-present actors that relentlessly maximize profits and externalize harm," as well as to turn from an overemphasized denunciation of business harms at the expense of a more agnostic inquiry that may include the social benefits of business as well (Welker et al 2011: s5-s6).

We recommend an historical anthropology of business that concerns itself with the shifting stability of business enterprise (Gordon forthcoming), as well as a theoretical view that holds simultaneously in sight "top-down" and "bottom-up" perspectives on the history and present context of business firms (Orts 2013: 9-17, 253-56). As the development of the use of historical methodologies in anthropology makes clear, the various ways in which one might engage with the shards and the stories of the past have deep theoretical implications in addition to the practical ones. Historicizing the business firm, in steering clear of representations characterized by either a monolithic smoothness or an unrealistic supposition of contingency and malleability, requires, as Ortner argued, "the retrieval of both dimensions - everyday practice and tacit consciousness on the one hand, purposeful projects and strategic consciousness on the other" (2001:82). In the process, our knowledge of business institutions and the participants in them will likely be advanced in surprising and deeply revealing new directions.

\section{References}

Abrams, Philip 1988. "Notes on the difficulty of studying the state (1977)." Journal of Historical Sociology 1(1): 58-89.

Aiello, Leslie C., and James F. Brooks, eds. 2011. “Corporate lives: new perspectives on the social life of the corporate form." Current Anthropology 52(S3).

Allison, Anne 1994. Nightwork: Sexuality, pleasure, and corporate masculinity in a Tokyo hostess club. Chicago: University of Chicago Press.

Ballard, Chris and Glenn Banks 2003. "Resource wars: the anthropology of mining." Annual Review of Anthropology 32: 287-313.

Benson, Peter, and Stuart Kirsch 2010. "Capitalism and the politics of resignation." Current Anthropology 51(4): 459-486.

Berger, Peter, and Thomas Luckmann 1967. The social construction of reality. Garden City, New York: Doubleday.

Carrier, James G. 2013. "Business Literature and Business Understandings of Business." Journal of Business Anthropology 2(2): 12032 .

Cattelino, Jessica R. 2011. "One hamburger at a time: revisiting the statesociety divide with the Seminole Tribe of Florida and Hard Rock 
International." Current Anthropology 52(s3): s137-s149.

Clark, Rodney 1979. The Japanese company. New Haven: Yale University Press.

Comaroff, John. L. 1982. "Dialectical systems, history and anthropology: Units of study and questions of theory." Journal of Southern African Studies 8(2): 143-72.

Comaroff, Jean, and John L. Comaroff 1991. Of revelation and revolution, volume 1: Christianity, colonialism, and consciousness in South Africa. Chicago: University of Chicago Press.

Comaroff, John L., and Jean Comaroff 1992. Ethnography and the historical imagination. Boulder: Westview Press.

Dirks, Nicholas B., Geoff Eley, and Sherry B. Ortner 1994. "Introduction to Culture/Power/History." Culture/Power/History: 3-46.

Dolan, Catherine, and Dinah Rajak 2011. "Introduction: ethnographies of corporate ethicizing." Focaal 60(1): 3-8.

Dolan, Catherine, Christina Garsten, and Dinah Rajak, eds. 2011.

"Corporate ethicizing." Focaal 60(1).

Ehrenreich, Susanne 2010. "English as a business lingua franca in a German multinational corporation: meeting the challenge." International Journal of Business Communication 47(4): 408-431.

Ferguson, James 1994. The anti-politics machine. Minneapolis: University of Minnesota Press.

Fortun, Kim 2001. "Advocacy after Bhopal." Environmentalism, Disaster, New Global Order: Chicago and London: University of Chicago Press.

Foster, Robert 2010. "Corporate oxymorons and the anthropology of corporations." Dialectical Anthropology 34(1): 95-102.

Gordon, Gwendolyn, forthcoming. "The contingent corporation: ethnographic insights into the nature of the firm."

Greenhouse, Carol 1996. In a moment's notice: Time politics across cultures. Ithaca: Cornell University Press.

Gusterson, Hugh 1997. "Studying up revisited." PoLAR: Political and Legal Anthropology Review 20(1): 114-119.

Ho, Virginia Harper 2012. "Theories of corporate groups: corporate identity reconceived." Seton Hall L. Rev. 42: 879-951.

Ho, Virginia Harper 2013. "Of enterprise principles and corporate groups: Does corporate law reach human rights?" Columbia Journal of Transnational Law 52: 113-72.

Iwai, Katsuhito 1999. "Persons, things and corporations: The corporate personality controversy and comparative corporate governance." American Journal of Comparative Law 47: 583-632. 
Jain, S. Lochlann 2011. "Survival Odds." Current Anthropology 52(S3): s45s55.

Kirsch, Stuart 2006. Reverse anthropology: Indigenous analysis of social and environmental relations in New Guinea. Stanford: Stanford University Press.

Maitland, F.W. 1936. Selected essays. Cambridge: Cambridge University Press.

McDonald, Terence J., ed. 1996. The historic turn in the human sciences. Ann Arbor: University of Michigan Press.

Merry, Sally Engle 2011. "Measuring the world." Current Anthropology 52(S3): s83-s95.

Millon, David 1990. "Theories of the corporation." Duke Law Journal 1990: 201-262.

Millon, David 2001. "The ambiguous significance of corporate personhood." Stanford Agora: An Online Journal of Legal Perspectives 2.

Miyazaki, Hirokazu, and Annelise Riles 2005. "Failure as an endpoint." Global assemblages: Technology, politics, and ethics as anthropological problem: 320-31.

Moeran, Brian 1996. A Japanese advertising agency: An anthropology of media and markets. London: Curzon.

Moore, Sally Falk 1987. "Explaining the present: Theoretical dilemmas in processual ethnography." American Ethnologist 14(4): 727-36.

Nader, Laura 1972. "Up the Anthropologist." Reinventing Anthropology: 284-311. New York: Pantheon Books.

Nash, June C. 1979. "Anthropology of the multinational corporation." The politics of anthropology: From colonialism and sexism toward a view from below: 421-446.

Nash, June C. 1989. From tank town to high tech: The clash of community and industrial cycles. Albany: SUNY Press.

Ortner, Sherry B. 1989. "Cultural politics: Religious activism and ideological transformation among 20th century sherpas." Dialectical Anthropology 14(3): 197-211.

Ortner, Sherry B. 1994. "Theory in anthropology since the sixties." Culture/Power/History: 372-411.

Ortner, Sherry B. 2001. "Specifying agency: The Comaroffs and their critics." Interventions 3(1): 76-84.

Orts, Eric. W. 1998. "Shirking and sharking: A legal theory of the firm." Yale Law \& Policy Review, 16: 265-329.

Orts, Eric W. 2013. Business persons: A legal theory of the firm. Oxford: Oxford University Press. 
Orts, Eric W. (forthcoming). Rethinking the firm: An interdisciplinary interpretation. Oxford: Oxford University Press.

Partridge, Damani James 2011. "Activist Capitalism and Supply-Chain Citizenship." Current Anthropology 52(S3): s97-s111.

Rohlen, Thomas P. 1974. For harmony and strength: Japanese white-collar organization in anthropological perspective. Berkeley and Los Angeles: University of California Press.

Ruskola, Teemu 2000. "Conceptualizing corporations and kinship: Comparative law and development theory in a Chinese perspective." Stanford Law Review 52: 1599-1729.

Ruskola, Teemu 2005. "Home economics: What is the difference between a family and a corporation?" Rethinking commodification: cases and readings in law and culture. New York: New York University Press.

Ruskola, Teemu 2014. "What is a corporation? Liberal, Confucian, and socialist theories of enterprise organization (and State, family, and personhood)." Seattle University Law Review 37: 637-662.

Sawyer, Suzana 2004. Crude chronicles: Indigenous politics, multinational oil, and neoliberalism in Ecuador. Durham: Duke University Press.

Sepinwall, Amy J. 2012. "Citizens united and the ineluctable question of corporate citizenship." Connecticut Law Review 44: 575-1725.

Silbey, Susan S., and Austin Sarat 1987. "Critical traditions in law and society research." Law and Society Review 21(1): 165-174.

Spear, Thomas 1994. "History or anthropology?" (book review). Journal of African History 35(1): 133-34.

Subramanian, Ajantha 2010. "Comment." Current Anthropology 51(4): 479-480.

Urban, Greg and Kyung-Nan Koh 2013. "Ethnographic research on modern business corporations." Annual Review of Anthropology 42: 13958.

Welker, Marina, Damani J. Partridge, and Rebecca Hardin 2011. "Corporate lives: New perspectives on the social life of the corporate form." Current Anthropology 52(S3): s3-s16.

Welker, Marina 2009. "Corporate security begins in the community': Mining, the corporate social responsibility industry, and environmental advocacy in Indonesia." Cultural Anthropology 24(1): 142-79.

Welker, Marina n.d. "Notes on the difficulty of studying the corporation" (Unpublished manuscript, n.d., part of the Third Annual Adolf A. Berle Jr. Symposium). 


\section{Can Business History and Anthropology Learn from Each Other?}

Per H. Hansen, Copenhagen Business School, and

R. Daniel Wadhwani, University of the Pacific and Copenhagen Business School

Let's admit it up front: we are business historians and no experts on business anthropology at all. However, reading through some of the scholarly literature on business anthropology, we have come to believe that there are certain similarities in intellectual concerns and practices between it and our own field of business history.

Some of these similarities reflect common origins and longstanding concerns of the two disciplines. Historians, like anthropologists, are fundamentally concerned with context and with idiographic understanding, and complain incessantly about how simplified and stylized versions of history and culture appear in the nomothetic approaches that predominate in other business disciplines. But this sense of similarity has also grown as business history itself has evolved to embrace cultural - one might even say anthropological - interpretations of the history of enterprise.

In a way, business history and business anthropology may seem an odd couple to compare because, until recently, few would have seen any meaningful relationship between the two whatsoever. Business history, as it was practiced for most of the 20th century, had little interest in anthropology and a very one-dimensional view of culture, while anthropology, on the other hand, did not see business as an object of study until the late twentieth century.

Nevertheless, we believe that today business historians and business anthropologists actually have something to offer each other as well as other fields within organizational, business and management research. In this essay we first briefly describe the development of the field of business history in the 20th century and why the moment might be right for a meaningful exchange with business anthropology. Then we proceed to discuss three issues that we think are important for both business history and business anthropology and from which the disciplines might have something to learn from each other: the uses-ofhistory approach, contextualization and empirical material.

\section{Business history as a field}

Like all other academic fields and disciplines, business historians have spent a great deal of time figuring out exactly "what is business history." It 
is, of course, like shooting at a moving target, since the field, like most others, has developed significantly over time with respect to topics, research questions and analytical strategies.

As an institutionalized field, business history came of age, perhaps, before World War II when Harvard Business School began publishing the Bulletin of the Business Historical Society in 1926. The interest in the history of business, however, had earlier origins in nineteenth-century historical schools of economics that viewed historical studies of enterprise and entrepreneurs as an important counterweight to classical and neo-classical economics' highly theorized and equilibrium-oriented views of markets.

In history, these scholars saw the opportunity to emphasize instead the agency of actors, the importance of mind and will in economic processes, and a capitalist economy fundamentally characterized by disruption and change rather than equilibrium. It was, in fact, this sense that history was fundamentally practical, in dealing with "real" contexts and real people in the economic world, as opposed to the abstract and highly theorized nature of economics that shaped its early establishment as a discipline in a few business schools.

In the postwar period, the discipline was particularly shaped by Schumpeterian ideas about entrepreneurs and entrepreneurship, which itself was deeply indebted to the nineteenth-century historicist tradition. Schumpeter called for and briefly inspired a wave of cross-disciplinary research that sought to examine entrepreneurship and its role in economic change and development (Wadhwani 2010).

Beginning in the 1960s, however, the focus of the field shifted in two ways. One was that it became increasingly focused on economic explanations and economic methods, particularly with the rise of the new economic history. The other, ultimately more influential development for the field, was that this focus shifted from understanding of entrepreneurial actors and their contexts to the organization of big business - primarily driven by Alfred D. Chandler and his work on Strategy and Structure (Chandler Jr. 1962), The Visible Hand (Chandler Jr. 1977), and Scale and Scope (Chandler Jr. 1990). As a result, business history became increasingly focused on structure rather than individuals.

It was with Chandler's work that business history for the first time became recognized outside of the small group of practitioners. The reason was that the consulting firm McKinsey \& Company discovered Chandler's Strategy and Structure and decided to use it as a manual for consulting with big business in North America and Europe. Thus, probably for the first time ever, business history was used in a normative way to prescribe solutions to companies' strategic challenges. Not surprisingly, this increased the status of business history in business schools, but also reinforced its narrow focus on the strategy and structure of large firms. 
From the 1960s to the 1980s - or even the 1990s - business history could not have been further away from anthropology. If anything, most business historians at the time got their inspiration from functionalist transaction cost economics au Ronald Coase (Coase 1937) and Oliver Williamson (Williamson 1985). Most business historians subscribed to the basic, realist assumptions of neo-classical economics about rational, atomistic, utility-optimizing individuals - even with a dose of skepticism due to the messiness of business life, as shown by the empirical material.

During these years, the rift between business history and mainstream history grew, with little intellectual or methodological exchange between them. Thus, business history was little affected by the development of the new social history or the new cultural history. It also continued to subscribe to an objectivist view of the nature of firms and enterprise. The linguistic turn and Hayden White's work on Meta-history (White 1973) and narratives almost completely bypassed business historians without its being noticed, as did the growing use of ethnographic methods by historians.

However, during the 1990s something began to happen, and it could be argued that it was the so-called "cultural turn," with inspiration from semiotics and anthropology, that set things in motion. Part of this development came from the history discipline where cultural history and the related approaches became quite widespread during the 1980s and 1990s. Another part of the inspiration came from organizational scholars, especially from critical studies, who began taking an interest in historical perspectives on organizations (Rowlinson and Procter 1999, Rowlinson and Delahaye 2009).

It could, perhaps, be argued that the ground was fertile for a cultural turn in business history because quite a few business historians had been inspired by Douglass North's work in New Institutional Economics (North 1990, North 2005). While North's approach to NIE initially mostly led to analyses of the role of formal institutions, his own increasing emphasis on informal institutions and mental constructs and mindsets might have paved the way for a more intense focus on culture, norms, materiality and practices in business history.

While the inspiration from anthropology should not be overemphasized, there is no doubt that Clifford Geertz' The Interpretation of Cultures (Geertz 1973) - with its focus on thick description, meaning construction and a search for understanding rather than generalization became an important, and sometimes the only, work of reference for cultural approaches in history. The attention paid to Geertz was not least mediated by the micro-historical approach made popular by Nathalie Zemon Davis' (Davis 1983, Davis 1987) and Carlo Ginzburg's (Ginzburg 1980) pathbreaking studies.

The move towards cultural approaches in business history should not be overstated, however. In the Oxford Handbook of Business History 
published in 2008 the section on "approaches and debates" has chapters on "Business history and history," "Economic theory and business history," "Business history and economic development," "Business history and management studies," "The historical alternatives approach," and "Globalization," while any hint of cultural thinking is relegated to the very last chapter - 25 - "Business culture" (Jones and Zeitlin 2007). Likewise, in the chapter on "Business history and management studies," there is a section on "Stuck elsewhere: Business history between history and economics," but culture is mentioned only very briefly and anthropology not at all (Kipping and Üsdiken 2007).

Still, there is a realization among a growing sub-group of business historians that economics alone, and functionalist social science more generally, cannot deliver if one wants to understand the actions and worldviews of historical actors. If one wants to understand how and why historical actors made and gave sense to their world, and how and why formal and informal institutions developed and changed the way they did, business historians have to search for the construction of meaning and to understand the practices of historical actors. This search necessarily must go beyond the generalizing ambitions of economics, and focus on the specificity of time and space - in other words context, one of the issues we discuss briefly below (Bucheli and Wadhwani 2014).

Thus, some business historians have begun publishing articles and books that are at least to a certain degree inspired by an idea of the world - including the past - as basically culturally constituted. Business historians who are following these ideas are increasingly moving away from the traditional realist version of business history and are taking up narrative approaches that include the uses of history in and by organizations, actors and societies. These ideas on narratives and the uses of history are especially being pursued and developed at the Center for Business History at the Copenhagen Business School with which we are both affiliated (Hansen 2006, Hansen 2007, Mordhorst 2008, Hansen 2012, Hansen 2012, Mordhorst 2014).

We thus find ourselves at a moment in the evolution of the discipline when we think we may have a lot to learn from (and perhaps also to offer to) business anthropology. In the remainder of this essay, we briefly consider the three issues along which such an exchange could be productively organized: the uses of history approach, contextualization, and empirical material.

\section{The uses of history approach}

Historians and anthropologists alike agree that history matters. However, more often than not, this agreement is based on different visions of what is meant by history and how exactly it matters. For the anthropologist history matters as "living history," that is how historical narratives and 
rituals impact the lives of living agents in, say, an organization (Bate 1997). Traditionally, historians think - for obvious reasons - that history matters in and by itself; we write history on the premise that it is important to understand the origins and evolution of the present. However, for some business historians the turn toward culture has created an area of potential common ground with anthropologists in the newly emerging interest in the "uses of history."

In a uses-of-history approach, history - not the past, but narratives about the past - is seen as a way in which the human actors we study make sense of and give sense to their world. As far as we understand it, this is what anthropologists mean when they refer to "living history," and it seems to us that it most often indicates an unconscious use of history. However, actors and organizations often use history consciously in order to achieve certain objectives. When analyzing uses of history we therefore find it useful for analytical purposes to distinguish between phenomenological and instrumental uses of history.

Instrumental uses refer to the conscious use of history to achieve for instance strategic goals, while phenomenological uses of history refers to the deep embeddedness of all historical actors in historical narratives they cannot get out of. Actors can, so to speak, become trapped in their own historical narrative, and it is only by using history instrumentally and consciously that they can become aware of this entrapment and restory their organization in order to affect change. The Danish novelist Martin A. Hansen once said: "tradition is the fateful shape of history when it is not studied." The quote illustrates how an organization or a person can become trapped in its own historical narrative, in tradition.

Business historians have begun to examine the uses of history because it is both a potential enabler and a constraint on the perceptions, choices and actions of actors. Thus, historical narratives and sites of memory and identity create both remembering and oblivion, and path dependence that can be a strength for an organization under stable conditions when everything is going well, while it can turn into an obstacle to change when needed, due, for instance, to external pressure. In our own work we have found the "uses of history" line of thinking helpful in order to explain and understand how historical narratives shape organizations' and actors' choices (Hansen 2006, Hansen 2007, Mordhorst 2008, Khaire and Wadhwani 2010, Hansen 2012, Schwarzkopf 2012, Bucheli and Wadhwani 2014, Mordhorst 2014)(Linde 2009).

It strikes us that the "uses of history" approach could emerge as an important area of common interest for anthropologists and historians. The anthropological studies we have read have a deep understanding of how history, in the phenomenological sense described above, influences the way people make sense of their world and therefore how they act. From our perspective history comes to us in the shape of historical narratives and it is an important point that neither societies, nor 
organizations exist outside history. History is always with us in our ideas, perceptions and practices, and from our perspective a particularly promising field of future research lies in exploring when and how organizations use history consciously and instrumentally to achieve strategic or other goals, and to exercise and legitimize power.

\section{Contextualization}

Context is another area where the anthropologist and the historian have a shared view or concern. Context is important, we claim, because of the specificity of both anthropological and historical arguments. As idiographic disciplines the aim is not to present generalizations but to get a deep understanding of the subject that we analyze. As such, time and space are not abstractions but quite the opposite, they are crucial for understanding the actors and institutions that we examine.

Although any historian and anthropologist would instantly agree on the importance of context, things tend to get complicated when figuring out how to deal with it. Contextualization is not taught in historical method courses in history department, and it is our sense that historians and anthropologists treat context quite differently. Thus, there may be lessons for both fields in discussing the ways we contextualize.

It is our impression that most historians tend to look at context as structures and institutional frameworks conditioned by historical development - as something almost outside of the actors' world. Anthropologists, on the other hand, tend to see context as something that is constituted by the actors themselves as they go about living their lives. It is an open question which approach is the most fruitful, but there is no doubt that the question itself merits further discussion.

We see the problem of contextualization as in fact involving two related issues, each of which deserves both more reflection and constitutes shared challenges of research for historians and anthropologists. The first of these is the question of how actors make sense of their context. Insisting that actors and actions need to be understood in specific times and places inherently raises the question of how the actors themselves thought of their "place" and their "time." On this issue, we think our fellow historians could learn much from ethnographic approaches in understanding context more critically.

The second contextualization issue is the question of the contexts in which we choose to place our subjects. Historians and anthropologists do not and cannot just recount our subjects in their own contexts. For historians, this contextual decision is closely tied to how we periodize our subjects, particularly the assumptions we make about the relationship between our own period and that of the actors we study. In this regard, we think anthropologists may usefully borrow from historians in understanding how temporal boundaries, like cultural ones, operate in 
defining the contexts in which we place our subjects (Bucheli and Wadhwani 2014).

Any discussion of context, of course, also raises the question of the texts on which we base our interpretations. It is to the empirical bases of our disciplines that we turn next.

\section{Empirical material}

While historians and anthropologists tend to share some basic assumptions that history and context matter, one longstanding difference arises in the types of empirical materials we tend to prefer in examining how these things matter. While both disciplines are strongly empirically oriented, historians mostly rely on documents while anthropologists seem to us to use interviews and observation as their empirical foundation. Historians are usually skeptical of interviews - oral history because we prefer empirical material created in the time we study.

In this sense, historians have much to learn from anthropologists in the critical use of non-written empirical material. As historians' interest in the "uses of history" by actors grows, we will need to confront the question of the many forms that these uses take, and in this sense anthropological sources and methods certainly provide one way forward.

But historians also have much to offer anthropologists when it comes to the creative uses of written documents in research. While historical research sometimes continues to be inhibited by what Ludmilla Jordanova (Jordanova 2000) has aptly called "the cult of the archive," the evolution of history as a discipline has in fact been characterized by a dynamic expansion in the range of sources historians use and genuine creativity in their analysis and interpretation.

History, as a discipline, has expanded well beyond it's original practices of examining official political documents to embrace a wide range of sources for what they can tell us about the social and cultural lives of the subjects of study. Even more importantly, historical practices of interpreting these sources have evolved in ways that allow reading sources "against the grain" and in taking into account the voices of those other than the powerful.

As business historians and anthropologists delve more deeply into the uses of history by actors and into the questions of context, an engagement with these practices could prove particularly fruitful.

\section{Conclusion}

In this brief essay we have tried to raise a few questions about where business history and business anthropology have a shared interest. To a certain degree, both fields exist on the margins of the social sciences in 
business schools, but we feel very strongly that we both have much more to say than what is recognized by mainstream business school disciplines.

If business anthropology and business history are to increase our influence in the world of business education and research, one obvious starting point may be to engage in a fruitful conversation between our two fields. We hope that this essay will contribute in a small way to that conversation.

\section{References}

Bate, S. P. (1997). "Whatever happened to organizational anthropology? A review of the field of organizational ethnography and anthropological studies." Human Relations 50(9): 1147-1175.

Bucheli, M. and R. D. Wadhwani, Eds. (2014). Organizations in Time. History, Theory, Methods. New York, Oxford University Press.

Chandler Jr., A. D. (1962). Strategy and Structure. Chapters in the History of the American Industrial Enterprise. Cambridge, MA, MIT Press.

Chandler Jr., A. D. (1977). The Visible Hand. Cambridge, MA, The Belknap Press.

Chandler Jr., A. D. (1990). Scale and Scope. Cambridge, MA, The Belknap Press.

Coase, R. (1937). “The nature of the firm." Economica 4(16): 386-405.

Davis, N. Z. (1983). The Return of Martin Guerre. Cambridge, MA, Harvard University Press.

Davis, N. Z. (1987). Fiction in the Archives. Pardon Tales and Their Tellers in Sixteenth-Century France. Stanford, Stanford University Press.

Geertz, C. (1973). The Interpretation of Cultures : Selected Essays. New York, Basic Books.

Ginzburg, C. (1980). The Cheese and the Worms: The Cosmos of a SixteenthCentury Miller. London, Routledge.

Hansen, P. H. (2006). "Networks, narratives, and new markets: the rise and decline of Danish modern furniture design, 1930-1970." Business History Review 80(Autumn): 449-483.

Hansen, P. H. (2007). “Organizational culture and organizational change: a narrative analysis of the transformation of savings banks in Denmark, 1965-1990." Enterprise \& Society 8(4): 920-953.

Hansen, P. H. (2012). "Business history: a cultural and narrative approach.” Business History Review 86(4): 693-717.

Hansen, P. H. (2012). "Making sense of financial crisis and scandal: a Danish bank failure in the era of finance capitalism." Enterprise \& Society 13(3): 672-706. 
Jones, G. and J. Zeitlin, Eds. (2007). The Oxford Handbook of Business History, Oxford, Oxford University Press.

Jordanova, L. (2000). History in Practice. London, Arnold.

Khaire, M. and R. D. Wadhwani (2010). "Changing landscapes: the construction of meaning and value in a new market category-modern Indian art." Academy of Management Journal 53(6): 1281-1304.

Kipping, M. and B. Üsdiken (2007). "Business history and management studies." The Oxford Handbook of Business History. G. Jones and J. Zeitlin, Oxford University Press: 96-119.

Linde, C. (2009). Working the Past. Narrative and Institutional Memory. New York, Oxford University Press.

Mordhorst, M. (2008). "From counterfactual history to counter-narrative history." Management \& Organizational History 3(1): 5-26.

Mordhorst, M. (2014). "Arla and Danish national history. Business history as cultural history.” Business History 56(1): 116-133.

North, D. C. (1990). Institutions, Institutional Change and Economic Performance. Cambridge, Cambridge University Press.

North, D. C. (2005). "Institutions and the performance of economies over time." Handbook of New Institutional Economics. C. Menard and M. M. Shirley. Dordrecht: 21-30.

Rowlinson, M. and A. Delahaye (2009). "The cultural turn in business history." Entreprises et Histoire 55: 90-110.

Rowlinson, M. and S. Procter (1999). "Organizational culture and business history." Organization Studies 20(3): 369-396.

Schwarzkopf, S. (2012). "What is an archive - and where is it? Why business historians need a constructive theory of the archive." Business Archives (105): 1-9.

Wadhwani, R. D. (2010). "Historical reasoning and the development of entrepreneurship theory." The Historical Foundations of Entrepreneurship Research. H. Landström and F. Lohrke. Cheltenham, Edward Elgar: 343362.

White, H. (1973). Metahistory: The Historical Imagination in NineteenthCentury Europe. Baltimore, Md., The Johns Hopkins University Press.

Williamson, O. (1985). The Economic Institutions of Capitalism. New York, The Free Press. 


\section{Business History and Business Anthropology}

Geoffrey G. Jones, Isidor Straus Professor of Business History, Harvard Business School

Business historians are concerned with the historical evolution of firms and business systems. Like business anthropologists, they have always sought to observe what really happens. Typically, as they deal with the past, they have done this though research on the written archives of firms (and other institutions such as industry associations and governments) rather than ethnography, although it has become increasingly common to employ oral history in studies dealing with recent decades. My own recent studies, including a company history of the Anglo-Dutch consumer goods giant Unilever since 1965, a history of the global beauty industry, and a forthcoming history of green entrepreneurship, have relied to a growing extent on interviews with managers and entrepreneurs. ${ }^{44}$ The substantive difference with business anthropology is the emphasis on change over time. The value added of business history is the insight that things change, and that what we see today is contingent on events that have happened in the past.

The discipline has a lengthy history dating from the 1920s. This essay will focus on how the subject developed, not least to see if there are lessons business anthropologists might learn. ${ }^{45}$ I will leave it to others to discuss specific research methodologies.

The story is one of paradoxes. As a discipline, business history has generated an impressive wealth of knowledge about the history of business, especially in the United States, Europe and Japan. Individual business historians have made an enormous impact on other disciplines, especially management studies. Yet the story of business history as a discipline can hardly be described as a triumphant one. Although dealing with a central reality of modern life, capitalism and firms, professional business historians have spent decades bemoaning that few people read most of their painstaking studies. The subject appears inflicted by a permanent identity crisis, unsure of its borders and identity. In the crowded academic world of impact factors, this situation only seems to be getting worse.

The peculiar origins of the discipline are part of the explanation. It emerged as a discrete subject at the Harvard Business School in the late 1920s. It was the creation, then, of the most prestigious university in the

44 Geoffrey Jones, Renewing Unilever (Oxford: Oxford University Press, 2005); idem, Beauty Imagined (Oxford: Oxford University Press, 2010); Idem, Profits and Sustainability (forthcoming, Oxford University Press).

45 This essay draws extensively on the Introduction to Walter Friedman and Geoffrey Jones (eds.) Business History (Northampton, MA: Edward Elgar Publishing, 2014). This essay is fully documented. 
United States, and its pioneering and equally prestigious business school, but this not necessarily a recipe for success. The subject emerged as a result of the personal enthusiasm of the first two deans of the Harvard Business School, Edwin Gay and Wallace Donham, who believed that history had an important role to play in management education. Donham arranged for the foundation of the Isidor Straus Chair in Business History in 1927. The School's Baker Library became (and has remained) a major repository of manuscripts from the history of railroads, textiles, and other industries.

Harvard University at that time had an eclectic group of faculty members who were interested in business and economic history. Essential to the growth of the field were the works of a range of European-born theorists, including Joseph Schumpeter and Alexander Gershenkron, both of whom taught in the economics department at Harvard, and the sociologist, Talcott Parsons. But the core group of scholars was at Harvard Business School. N. S. B. Gras, a Canadian-born business historian who became the initial occupant of the Straus Chair, taught the first course on business history at the school and was known for his highly detailed empirical studies. Gras sought to focus the field on organization and management, and was noted for his conservative ideology. Arthur Cole, a business economics professor and librarian at Harvard Business School, helped to nurture the field. He stimulated interest in the topic of entrepreneurial history and helped to organize a Research Center in Entrepreneurial History, which lasted from 1948 to 1958. The Center was funded by the Rockefeller Foundation and included a multidisciplinary team of scholars, including Joseph Schumpeter.

This was a hybrid heritage. The new discipline researched the history of business using archival research, yet few of its practitioners were trained in history or worked in History departments. The initial location was in a business school, which trained future managers, and was never likely to prioritize the study of history. The intellectual inspiration was interdisciplinary. This was very helpful for understanding firms and their impact, but troublesome gaining traction as a mainstream academic discipline. From the beginning, the subject was led by dedicated scholars who saw the virtue of their field, but seldom received the accolades given to the stars of academia in higher profile subjects.

A number of the key challenges facing the subject were quickly identified. In an article written in 1952, for example, Fritz Redlich, an influential member of the Harvard group who was characteristically never tenured, expressed admiration for the rich empirical work of his colleagues, but also perceived a need to push the field forward theoretically. He wanted to make history more than a mere recitation of facts by employing theory and by generalizing. He argued that theory, drawn often from other disciplines, could help business historians to formulate problems and to make sense of change over time. However, 
Redlich cautioned, it was important not to be so theoretical as to lack concreteness. The real question of the field, he summarized, was, "How then is theory ... to be wed with the idea of historical uniqueness?" 46 This was a defining insight, but also one that was to prove challenging to execute.

There was a lengthy period when enthusiasts for the subject resembled prophets in the wilderness, believing strongly that they had something to say, but with no one listening. The most striking achievement, in retrospect, was the subject's interest in entrepreneurship, and that this differed between countries, and that firms were not uninteresting black boxes responding to supply and demand, but living entities who differed in their characteristics and pursued different strategies from one another. This was at a time when neoclassical economics was wholly unable to identify entrepreneurs and firms as objects of interest. Business historians proved unable to shift the situation.

The situation was further complicated by the fact that as the subject emerged beyond the United States, its intellectual focus was different. In Europe, business history emerged not out of business schools, but from the study of economic history. This strongly affected its intellectual goals and approach. In most of northern Europe, economic history was taught as a social science with closer links to economics than history. In my own case, before I arrived at the Harvard Business School I had never taught at a business school, or a History department, but rather in economic history or economics departments. This helped shape my own work in the history of international business, where I was enthusiastic about integrating history with the main economics theories of the multinational enterprise ${ }^{47}$ However, in the United States, the border between business and economic history became very strong as the latter became dominated by econometrics.

It was not until the 1960s that business history entered a golden age, which lasted for around three decades. The key figure was Alfred D. Chandler, whose most famous work appeared in three books about the rise of big business and the coming of a managerial class, beginning with Strategy and Structure published in 1962.48 Chandler was trained in history at Harvard University, and taught in the History department of

${ }^{46}$ F. Redlich, "The Role of Theory in the Study of Business History," Explorations in Entrepreneurial History, 4,3 (1952), p. 137.

47 Geoffrey Jones and Peter Hertner (eds.), Multinationals: Theory and History: (Aldershot: Gower, 1986); Geoffrey Jones, Multinationals and Global Capitalism (Oxford: Oxford University Press, 2005).

48 Alfred D. Chandler, Strategy and Structure: Chapters in the History of Industrial Enterprise (Cambridge, Mass.: MIT Press, 1962); The Visible Hand: The Managerial Revolution in American Business (Cambridge, Mass.: Harvard University Press, 1977); and Scale and Scope: The Dynamics of Industrial Capitalism (Cambridge, Mass.: Harvard University Press, 1990). 
Johns Hopkins University before taking the Straus Chair at Harvard Business School. However he had taken a sociology course at graduate school with Talcott Parsons, and this exercised a huge impact on both his interest in organizations, and his willingness to conceptualize.

So sweeping were these books that they set the terms for the field with the questions they raised: What was the relation of a firm's structure and strategy? Why did massive business enterprises develop in some industries and not others? How did the rise of big business in the U.S. compare with that elsewhere? These characteristics of Chandler's work big and important themes, empirically based arguments, comparative methodology, firm-centered studies - were inspiring to many scholars, not only business historians, but also those interested in strategy, entrepreneurship, and institutional economics. ${ }^{49}$ However, his work had limited impact on History as a discipline, and is now largely forgotten.

Chandler escaped the trap of the subject's marginalization. However, the sheer impact of Chandler's work was not without problems. It out-shone other work. There is a notable tendency, especially in disciplines such as strategy, to end the citation of business history research with Chandler, as if the subject had faded away. This is far from the case. There was other exciting work when Chandler was writing, by Lou Galambos, Mira Wilkins and many others. There has been a huge outburst of creative research since the 1990s, as the focus on large organizations has given way to more attention being paid to entrepreneurs, networks, business groups and other types of institution and organizational forms. These years have also seen a widespread institutionalization of the field, with new journals, associations and conferences.

It has proven hard, however, to duplicate Chandler's huge influence on managerial and social sciences. This is curious. From the 1980s many social sciences discovered that "history matters," and began developing theories that related directly to the traditional domains of business history, often undertaking their own empirical research rather than looking to research by business historians. The law and finance literature, for example, had an enormous impact with the argument that the legal tradition countries inherited or adopted in the distant past has a longterm effect on financial development.

Why wasn't business history able to benefit from this new interest in history? The problem, in my own view, is fundamentally methodological. Rich and nuanced empirical research has still not been translated sufficiently into convincing general propositions and concepts. More seriously, much business history research is still written as descriptive case studies which most social scientists are unable to identify

49 For a recent survey of this influence, see William Lazonick and David J. Teece (eds.), Management Innovation: Essays in the spirit of Alfred D. Chandler (Oxford: Oxford University Press, 2012). 
as scholarly research.

The biggest problem of all, however, has been a diffusion of research focus. Chandler's influence was so dominant that the next generation of business historians ran in all directions away from the study of large organizations. As a result the subject lost focus. A recent conference was even called the "business history of everything." A recent editorial of the journal of Business History Review, written by myself and Walter Friedman, called for a renewed focus on central issues that would gain the attention of scholars beyond the field. Three of the issues they identified - innovation, entrepreneurship, and globalization - were strongly represented in the past of the discipline. Three others - business and the environment, government, and democracy - were more radical departures for the field..$^{50}$

Going forward, there has long been a widespread recognition that business history needed more generalization and conceptualization to enhance its impact. There was also a widespread recognition that the theories developed in cognate social sciences could be a valuable tool to achieve this greater conceptualization. Yet there was no consensus on how to extend the forging of stronger links between theory and history. Different business historians looked to different social sciences, and different theories, for inspiration. The willingness to tolerate abstraction varied. More challenging still was the distant relationship with the discipline of history which, especially in the United States, has a preoccupation with culture, gender and the marginal at the expense of any interest whatsoever in business. Attempts to realign the research agenda of business history to issues related to culture, politics, gender relations, and the like have produced important scholarship but added to the diffuse nature of the field.

The story of business history as a discipline, then, is one of mixed news. Since the 1920s business historians have achieved much through their willingness to confront and understand the complexity of business, rather than rely on simplified models and unrealistic assumptions. It has proved a real struggle to get a wider circle of scholars to listen to much of this research. Finally, however, it is important to end on a positive note. In particular, business history has gained immensely through collaboration with other disciplines, when done right. This special issue presents a great opportunity to start another dialogue beneficial to both parties.

50 "Business History: Time for Debate," by the editors of Business History Review. 


\section{Business History and Anthropology}

Philip Scranton, Board of Governors Professor of History Emeritus, Rutgers University, and Editor-in-Chief, Enterprise and Society: The International Journal of Business History

"We do not know in what guise Herodotus traveled... As a merchant? Probably not, since he had no interest in prices, goods, markets... As a tourist? No, tourists travel to rest, whereas Herodotus works hard on the road - he is a reporter, an anthropologist, an ethnographer, a historian."

Ryszard Kapuściński, Travels With Herodotus (New York: Knopf, 2007, 79) 51

In Kapuściński's view, history, anthropology, journalism and ethnography once blended together seamlessly in Herodotus' chronicles of ancient wars, politics, customs and follies. Yet in his era, and for two millennia thereafter, businesses remained intellectually peripheral to proper European histories; meanwhile, developing alongside $19^{\text {th }}$ century colonialisms, anthropology explored the West's cultural and spatial peripheries. Unsurprisingly, America, a "business civilization," 52 provided the terrain (and the origin tales) for business history as a discipline, as well as a venue for considering business practices anthropologically, as cultural performances thick with rituals and totems. For the last half century, building links between history and anthropology has also been urged, both by postcolonial anthropologists re-emphasizing power, context, and change over time, and by historians making the 'cultural turn,' stepping away from narratives anchored in 'past politics.' Clifford Geertz sensed the deeper resonances (or shared constraints) that Kapuściński highlights: "Dealing with a world elsewhere comes to much the same thing when elsewhere is long ago as when it is far away." Yet, Geertz continued, "We' means something different, and so does 'they', to those looking back than it does to those looking sideways, a problem

51 For biographical information about this remarkable "literary journalist" from Poland (1932-2007), visit http://en.wikipedia.org/wiki/Ryszard_Kapu\%C5\%9Bci\%C5\%84ski

52 See James Truslow Adams, Our Business Civilization: Some Aspects of American Culture, New York: Boni, 1929; Herman Krooss, American Economic Development: The Progress of a Business Civilization, Englewood Heights, NJ: Prentice Hall, 1966; and Robert Heilbroner, Business Civilization in Decline, New York: Norton, 1976. Announcing his flashy monthly business magazine, Fortune, in 1930, Henry Luce positioned it as presenting "the challenging personalities, significant trends, and high excitements of this stirring civilization of Business." [Quoted in Nigel Thrift, "Performing Cultures in the New Economy," Annals of the American Academy of Geographers 90(2000): 674-692, quote at 678.] 
hardly erased when, as is increasingly the case, one tries to do both."53 There would be no anthropology-history merger and no harmonization, but ambiguous encounters and serial appropriations multiplied instead.

Perhaps anthropologists wished to delve into historical time, but without utilizing historians' research methods; certainly cultural historians sought to appropriate anthropological concepts, but rarely plunged into learning fieldwork techniques and applying them. Nevertheless, a considerable body of "historical anthropology" has emerged, including a journal, ${ }^{54}$ alongside a stream of anthropologicallyinflected historical essays and monographs. ${ }^{55}$ (I don't know whether historians and anthropologists have constituted joint efforts for research and mutual edification, though there are a few joint graduate programs. If such projects happened, reviewing their results could be valuable.) Nonetheless, in all this connectivity, businesses barely surfaced, but that near-silence is now ending. ${ }^{56}$

Perhaps fruitful collaboration between anthropology/ethnography and business history is feasible, but it would, I'd imagine, involve a demanding double-move. First, business historians would have to generate research initiatives that, far more than to date, address nonWestern, colonial and post-colonial sites of business activity and organization. This would displace our durable emphasis on Western traders' and multinationals' incursions 'elsewhere'; and prioritize those local/regional/transnational networks activated before, during, and after

53 Clifford Geertz, "History and Anthropology," New Literary History, 21(1990): 321-35, quote from 323. In part Geertz traced the new intersections to "a collapse of the natural dispersion of feeding grounds" that handed France to historians and Samoa to anthropologists (324).

54 History and Anthropology, which reached Vol. 25 in 2014. My walk-through of the journal's last 20 years unearthed a handful of articles referencing business matters, chiefly tourism, but just one that speaks directly to business history: Manos Spyridakis, "The Political Economy of Labor Relations in Greek Shipbuilding: An Ethnographic Account," H\&A 17(2006):153-170, which treats the decades after 1970. There does not appear to be a journal of Anthropological History, suggesting a thinner reach by historians toward anthropology (especially scholars addressing postcolonial questions). For work in this vein, see Eric Tagliacozzo and Andrew Willford, Clio/Anthropos: Exploring the Boundaries Between History and Anthropology, Stanford: Stanford University Press, 2009. For a business history approach to tourism, with some anthropological resonances, see The Business of Tourism: Place, Faith and History (Philip Scranton and Janet Davidson, eds.), Philadelphia: Penn Press, 2009.

55 Since the late 1980s, I have introduced cohorts of beginning graduate students to Rhys Isaac's The Transformation of Virginia (Chapel Hill: University of North Carolina Press, 1982), in order to underscore the multiplicity of methods and rhetorics scholars can employ in addressing historical questions. Many found it provocative and insightful, but others rejected Isaac's explicit attention to methodology and his fabrication of social/cultural structures from scattered images and texts. For an appreciation of Isaac's "Melbourne group," see Geertz, "History and Anthropology," 325-29.

56 Reasons for this are amply outlined in Alan Macfarlane, "Historical Anthropology," Cambridge Anthropology 3:3 (1977): 1-17. 
periods of Euro-American dominion. In my view, Michael Miller has brilliantly accomplished this in his revelatory Europe and the Maritime World, ${ }^{57}$ where readers learn about complex Asian, African and Middle Eastern production, trading, credit and transport systems within which Westerners struggled for profit and advantage. Miller's persistent and insightful engagement with diverse cultures and practices in the Indian Ocean region - including rituals, symbols, conventions, taboos, and kinship ties - draws business history and anthropology together in richlyimplicative ways. Re-visioning business activity from the perspective of the "locals" - regional elites, religious communities, autonomous business groups - shifts the interpretive motif from Europeans "acting on" others to the immense complexities of Westerners and Easterners "acting with" one another. To be sure, Miller's mastery of multiple languages and the literatures detailing non-Western trading/shipping operations sets a very high bar for emulators, but teamwork is feasible.

Second, anthropologists could usefully expand historically the recent proliferation of business ethnographies, reinforcing critical scholarly perspectives while drawing on historical periodizations and promising initiatives in social theory. ${ }^{58}$ In so doing, they might find it useful to return from post-colonial domains to the industrial/commercial West, to its urban business centers, and its complex organizations seeking to shape capitalist futures. Scholarly investigations can document and critique their ritual and symbolic endowments and their transformations, treated contextually and dynamically. ${ }^{59}$ This historicizing potential may be seen by contrasting two works by anthropologists: Karen Ho's riveting Liquidated: An Ethnography of Wall Street and Melissa Fisher's remarkable Women of Wall Street. ${ }^{60}$ Ho secured employment as a securities analyst early in graduate school, aiming to undertake Wall Street participant fieldwork, but was laid off before her two-year 'apprenticeship' could be completed. Determined to explore this tribal environment of intense pressure and insecurity, she returned to "the belly of the financial markets" 61 for almost two more years, before leaving to finish her doctorate. The monographic outcome is deeply historical, as Ho

\footnotetext{
57 New York: Cambridge University Press, 2013, paper 2014.

58 There seems to me to be a substantial gap between scholarly assessments, like Brian Moeran's The Business of Ethnography (2005), and the many online purveyors of business anthropology as services for corporate marketing, strategy, or product development. This gap lay just beneath the surface of the JBA's 2013 forum on "Ethnographic Methods in the Study of Business," notably when setting the cruise ships and GM accounts alongside the Austrian dissertation project and Gary Fine's reflections on kitchen work. Theoretical work that seems to me valuable in this arena has been offered by Richard Sennett, Ulrich Beck, Bruno Latour, and Zygmunt Bauman, among others. ${ }^{59}$ Some suggestions along these lines, admittedly framed for business historians, can be found in Philip Scranton and Patrick Fridenson, Reimagining Business History, Baltimore: The Johns Hopkins University Press, 2013.

60 Both Duke University Press, Ho in 2009, Fisher in 2012.

$61 \mathrm{Ho}$, ix.
} 
chases Wall Street rhetorics, values, and concepts back through the twentieth century (e.g., "shareholder value"), analyzes prior cycles of boom and bust, explores key investment banks' institutional histories, skewers entrenched, gendered customs/expectations, and then, from a post-2008 crash perspective, reviews her 1990s fieldwork experiences as historical evidence. Fisher works a different frontier, researching the first generation cohort of women Wall Streeters from the 1960s forward, by way of archival research, extensive interviewing of articulate veterans, and fieldwork in financial women's professional and political associations. Her monograph unfolds chronologically, moving from women's experiences to contexts to institutions, from celebratory events to support networks to the challenges of family and motherhood. Its conceptual spine is the intersection of feminism and market dynamics, in shifting economic and institutional environments where women are "the Other" just about always. Ho's book provides a historicized anthropology and Fisher's exemplifies an anthropologized history, each distinct and both compelling. A related and vivid analysis that engages consumption rituals historically is Milena Veenis's Material Fantasies: Expectations of the Western Consumer World among East Germans, in which Coca Cola cans and blue jeans figure prominently amid a Cold War culture of suspicion and betrayal. ${ }^{62}$

After this extended opening, I expect it's time to respond to the editors' requests to contributors, which were: first, how do I approach the study of business and the economy?; second, what such an approach can and cannot offer anthropologists; and third, what I think anthropologists do well (or badly) that business historians might pay attention to (or ignore). On the first count, I approach business and economic matters warily and with skepticism, especially toward narratives and evidence that emphasize rationality, planning, efficiency, success, and the visions/wisdom/insights of managers, investors, and entrepreneurs. Much business activity is repetitive and uninteresting routine, and much of what happens outside that area is messy - actions that are unpredictable, irrational, conflictual, deceptive, unintended, catastrophic, and thus intriguing. Historically, as Patrick Fridenson and I have suggested, actors retrospectively fashion rational orderings of non-linear, indeed chaotic or sloppy, efforts. These tidy tales prove useless to later actors, as they misconstrue the past in the service of creating logical paths to the present. 63 Thus one key to restoring or reconstituting historical dynamics is to marshal documentation that presents agents looking forward into buzzing alternatives, armed with fragmentary information, rule-of-thumb analogies, and incomplete knowledge about the backgrounds of, and environments for, decision-making.

\footnotetext{
62 Amsterdam University Press, 2013. See also Milena Veenis, "Cola in the German Democratic Republic: East German Fantasies on Consumption," Enterprise and Society 12(2011): 489-524.

${ }^{63}$ See Scranton and Fridenson, Reimagining, Sections 1.5, 2.11, 3.11, and 4.4.
} 
Thus, in my current research on the Cold War development of jet propulsion by corporations and military forces in Britain, France and the US (ca. 1942-62), I distrusted from the outset various "triumph of reason" stories deployed in institutional histories, read with caution stacks of technical journal articles, yet found in participants' memoirs tales hinting at the hazards and uncertainties of urgency-driven innovation. The closer to the design offices and engine test-beds I could get, the more unruly the development processes appears. Ultimately, access to declassified archival documents and to project histories drafted during testing, redesign and production (or soon after) revealed cascades of errors, failures, and fixes that, in time and at staggering costs, yielded reliable military jet engines. Some managerial teams proved consistently effective (General Motors - Allison Division, and Pratt \& Whitney, for example), others were better at design and testing than at production (General Electric, at least initially), and some were simply underpowered, or hopeless in their overconfidence (Westinghouse, Curtiss-Wright). ${ }^{64}$

Little of the above links to anthropology directly, but midway through the research I revisited publications by several of the Xerox PARC anthropologists, when preparing to discuss John Seely Brown and Paul Duguid, The Social Life of Information, in a graduate "history and theory" colloquium. This led me to look more closely at an aspect of jet propulsion's material culture: the forms and procedures French and U.S. air forces used to track their jet engines in use and repair, and to analyze their collective performance. I pulled the essay collection, Anthropological Perspectives on Technology, off the shelf and revisited contributions by Richard Wilk, Lucy Suchman, Richard Gould and the editor, Michael Brian Schiffer. ${ }^{65}$ This led to drafting a speculative essay asking ethnographicstyle questions of historical, technical jet propulsion documents; it would probably not stand close scrutiny by anthropologists, but has triggered energetic seminar discussions among historians. ${ }^{66}$

64 Similar distributions of competence and resources occurred in the UK, with Rolls-Royce leading the pack. In France, one nationalized company (SNECMA) did most of the heavy lifting, whereas Hispano-Suiza copied UK engines through licenses, and Turbomeca focused on small, lightweight propulsion units for trainer aircraft and helicopters. For examples of this project's research findings, see Philip Scranton, "Technology-Led Innovation: The Non-Linearity of U.S. Jet Propulsion Development," History and Technology 22:(December 2006): 337-67; Idem., "Turbulence and Redesign: Dynamic Innovation and the Dilemmas of US Military Jet Propulsion Development," European Management Journal 25 (June 2007): 235-48; and Idem., "Mastering Failure: Technological \& Organizational Challenges in British and American Military Jet Propulsion, 1943-1957," Business History 54 (July 2011): 479-504.

65 See Wilk, "Toward an Anthropology of Needs"; Suchman, "Building Bridges: Practice-based Ethnographies of Contemporary Ethnography"; Gould, "From Sail to Steam at Sea in the Late Nineteenth Century"; and Schiffer, "Toward an Anthropology of Technology," in APT, Albuquerque: University of New Mexico Press, 2001. 66 Philip Scranton, "Histories and Historical Ethnographies of Technical Practice: Managing Jet Propulsion in the US and France," forthcoming Entreprises et 
Next, what can this approach to business history (and the history of technology, evidently) offer anthropologists? Three things, most simply encounters with power, access to institutional dynamics, and perspectives on contingency. Probing businesses historically opens the way to appreciating how power is achieved, exercised and reproduced/destroyed in social and economic relations, within and among organizations. Power operates in business, in fair measure, through rituals and artifacts: the hiring relation (and the firing memo/exit interview), the annual review, seating arrangements at key meetings, budget battles in product development or marketing, the annual bonus, the hand-tailored suit, the $\$ 1000$ bottle of burgundy, the Rolex, Bentley, and penthouse apartment. Yet power exists only in its performance and can vanish overnight following a merger, a hostile takeover, a bankruptcy declaration, a criminal indictment. These dynamics capture the contingency of corporate existence, just as the unexpected flood, lawsuit, or vengeful ex-employee can expose the vulnerabilities of small enterprises. Though big business may seem monumental and durable, this is far from accurate when viewed over time. Few of the Top 50 US corporations in 1960 still figure in current-day lists of America's major companies, something a review of the frequent rotation of the Dow Industrial Index's membership would emphasize. Currently its 30 components include Microsoft, Nike, Visa, Wal-Mart, and Walt Disney, none of which featured as economic leaders a half-century ago. Among other possibilities, business history can help anthropologists grasp the centrality of failure in capitalism, a dimension equally as important as competition, innovation, or hierarchy.

Last, what do anthropologists do well that business historians should appreciate (I'll avoid the "do badly" invitation)? This, too, seems pretty straightforward to me. Business historians can readily become overly focused on organizational forms/structures, quantitative measures of performance, and the politics of enterprise (internal, sectoral, and state-related). Narrating change is central and change is frequent. However, more complex analyses can arise through taking into account aspects of business culture which make communication, identity, and continuity feasible, and perhaps the roles their inflation or breakdowns play in fostering or forcing change. These non-economic elements in business activity profoundly condition how managers frame and solve problems, how investors (and regulators) value information and commit to action, or how entrepreneurs conjecture present options and future goals. They are embedded in institutional rituals historians easily overlook, bubble up in relational imagery (businesses as "a family" or as a "warrior clan"67), and animate descriptions of corporate life that

Histoire, (No. 70, Summer 2014).

67 For the latter see Scott Patterson, The Quants: How a New Breed of Math Whizzes Conquered Wall Street and Nearly Destroyed It, New York: Random House, 2010. 
invigorate anthropological fieldwork accounts. Reading contemporary business anthropology can serve as a "sensitizing device," as Anthony Giddens put it, ${ }^{68}$ enabling historians to recognize and research aspects of business behavior that would otherwise be taken for granted and passed over. Such reading has been invaluable in my own work, and has solid potential to enrich business history research hereafter. What I do wish, though, is that sustained opportunities could be framed for colleagues in anthropology and business history to talk and work together to explore collaborations in research and conceptual development. That truly would be a treat.

\section{Business History and Business Anthropology: Some Reflections and Suggestions}

Daniel Pope, Professor Emeritus, University of Oregon

Historians have been notoriously resistant to the siren calls of theory. We burrow into our sources and revel in constructing evidence-based narratives. This, of course, has left plenty of room for implicit (perhaps even unconscious) theorizing to creep through the rear door of the narratives we construct. The field of business history, however, is one area that acquired its own paradigm close to half a century ago. Alfred D. Chandler, the late Straus Professor of Business History at Harvard Business School, outlined it in pathbreaking books and articles in the 1960s and filled it with rich detail in his 1977 masterwork, The Visible Hand: The Managerial Revolution in American Business, awarded the Pulitzer Prize in History. Broadening his approach to encompass other advanced economies, Chandler followed The Visible Hand with Scale and Scope: The Dynamics of Industrial Capitalism in 1990.

Chandler convinced business historians that the rise of big business firms was the central phenomenon of capitalism since the mid-nineteenth century. Big businesses were qualitatively different organizations from lesser ones, marked by administrative coordination of activities, a separation of ownership and management, and organizational structures that evolved in tandem with their growth strategies. New technologies were usually the catalysts of organizational change and a flurry of them around the 1880s set a wide range of industries onto the big business path. For a field that had been mired in rather sterile controversies between left-wing and populist critics of robber barons and those who offered eulogies to captains of industry, Chandler's Weberian approach

${ }^{68}$ Anthony Giddens, The Constitution of Society, Cambridge: Polity, 1984. 
(as filtered through his own mentor, Talcott Parsons) was bracing. It seemed to discard moralizing for rigor and downplayed personal idiosyncrasies while delineating patterns of development. Perhaps most importantly, the Chandlerian perspective focused squarely on the most evident reality of the post-World War II era, the prominence of giant corporate enterprises in economic and social life, in the United States and in other advanced capitalist nations. Indeed, Chandler's approach spread beyond the confines of business history. Influential articles by Louis Galambos, for instance, outlined an "Organizational Synthesis" approach to modern American society. A decade before The Visible Hand, Robert Wiebe had undertaken The Search for Order (1977), a general history of the Gilded Age and Progressive Era in the United States with a distinctly Weberian emphasis on the growth of large-scale organizations.

Powerful and persuasive as it was (and still in many respects remains) to most business historians, to cultural anthropologists the Chandler paradigm must have seemed quite forbidding. Chandler himself, open-minded and receptive to varied approaches that differed from his own, had no intention of building a moat around the edifice he constructed for business history. Nevertheless, cultural factors played only a secondary role in explaining the rise of big business. To invoke them, Chandlerians sometimes suggested, was to substitute vague handwaving for explanation. Instrumental rationality determined business strategies and those strategies in turn shaped organizational structures. Consumers and workers stood in the margins of the picture when they appeared at all. Consumer preferences were largely exogenous. They could and did influence corporate choices, and marketing was a crucial corporate function, but the substance of producer-consumer interactions was rarely given center stage. Chandler himself and many of his disciples paid little attention to work and labor below the ranks of management. The Chandlerian firm dealt with challenges in recruiting, managing and retaining a workforce, negotiated with unions, encountered strikes, but these activities did not weigh heavily in setting the patterns of corporate development. The iron cages of bureaucracy may have been redesigned into managerial cubicles and suites, but the social interactions within them dropped out of the narratives. In discarding the heroes and villains approach, the Chandler paradigm, one business historian joked, threatened to be the field's neutron bomb - leaving structures standing while killing off the humans. Business historians rarely employed anthropological theories. Indeed, the names of Clifford Geertz and Marshall Sahlins, to choose two prominent and provocative figures, do not appear in searching the database for items in the Business History Review or Enterprise \& Society, the field's two premier U.S. journals. Conversely, Alfred Chandler's name is entirely absent from the Anthrosource and Anthropology Plus databases.

Somewhat ironically, the rise of the big business paradigm, with its apparent separation from anthropological perspectives, came at a 
moment when other subfields of history were moving closer to those perspectives. The "linguistic turn," the influence of Foucauldian concepts like micropolitics, normalization and the gaze, and the "return to narrative" in the 1970s and 1980s, all pointed in the direction of "cultural studies," a watchword that invoked the culture concept - even if it might (as an historian I can't speak with any authority on this) broaden and blur it beyond anthropological recognition.

Within business history, Chandler's work had never met with unqualified acceptance, although it loomed large even to those who doubted aspects of it. In recent decades, however, the paradigm has undergone what Richard R. John, in an important 1997 article, called "Elaborations, Revisions [and] Dissents." He pointed out the crossdisciplinary impact of Chandler's approach and, as well, its influence on management itself, but in his list of fields affected, anthropology is missing. John's article was anything but an attack on his own Doktorvater. In the first two sentences, he quite rightly labeled The Visible Hand "magisterial," "pathbreaking," and a "landmark." Yet the article signaled new inflections and new directions for the field of business history. In several respects, these have more potential than Chandler's own work to serve in a rapprochement of business anthropology and business history. I will briefly note some of the revisions and dissents that Richard John referred to and point to a few of the works that may be particularly stimulating for business anthropologists.

Why has the paradigm shifted? In the last few decades it has been hard to ignore the travails of big business firms, especially in manufacturing. When General Motors, a leading exemplar of Chandler's doctrines, goes bankrupt attention must be paid. The benefits of recent technological change seem to accrue to entrepreneurs more than to managers, and the new protagonists of business dramas are more apt to be wearing t-shirts than gray flannel suits. New York skyscrapers give way to Silicon Valley campuses, with their swimming pools and volleyball courts (along with, in the case of Google, a replica dinosaur skeleton, perhaps to remind denizens of their pre-postindustrial ancestors' fates). On a more academic plane, those tendencies which had nudged other historical subfields toward cultural approaches infiltrated the gates of business history. Perhaps most important, a sense that Chandlerian business history was too strongly determinist led many to turn to examining contingent factors and even to examining "alternative tracks," to borrow the title of a stimulating study by Gerald Berk (1994) of a railroad line whose business strategies contradicted the pattern of railroad growth that Chandler and his followers had traced.

One of the leading figures in newer - perhaps more anthro-friendly - scholarship in American business history is Philip Scranton. In several influential works, Scranton has given close, detailed accounts of textile and carpet production in the Philadelphia area. In his scholarship, firms 
engaged in batch production of specialty goods - the kind of manufacturing that clustered around Pennsylvania - were not bit players strutting briefly on the business stage before vertically integrated mass production firms pushed them to the wings. In Endless Novelty: Specialty Production and American Industrialization, 1865-1925 (1999), he broadens his geographic scope and describes a wide range of industries where batch production prevailed over mass production. In one of his books, Figured Tapestries: Production, Markets and Power in Philadelphia Textiles 1885-1941 (1989), he acknowledges debts to scholars in half a dozen disciplines; anthropology is not among them, but with its attention to language and imagery, labor, gender, technological change and resistance, consumer behavior, style and fashion, Scranton's work exemplifies many of the qualities that should make cultural anthropologists feel comfortable in its milieu.

Another historian whose scholarship captures many current motifs of business history is Regina Blaszczyk. Her first book, Imagining Consumers: Design and Innovation from Wedgwood to Corning, made the case that success in household goods - from tableware to plumbing fixtures - depended less on economies of scale, scope and speed (key success factors in the Chandler paradigm) than on knowledge of consumer desires and an ability to accommodate them. Firms sensitive to style and fashion trends and flexible enough to produce what consumers wanted, she argued, were those that thrived in such industries. She explains how firms learned about their consumers, and while cardcarrying anthropologists are not present in her story, the "fashion intermediaries"- "practical men, shopkeepers, salesmen, retail buyers, materials suppliers, art directors, showroom managers, color experts" parallel the "native informants" who used to serve the pith-helmeted ethnographers in their fieldwork.

Blaszczyk extended her approach to business history in an overview of American Consumer Society, 1865-2005: From Hearth to HDTV. Again, consumer agency, interaction between producers and consumers, and a diverse and shifting set of motives and satisfactions in consumption are themes. Anthropologists interested in material culture will be impressed with a history that pays close attention to what people actually had and used in their homes and what those goods meant to them. More celebratory of the society it portrays than I would be, Blaszczyk nevertheless recognizes some of the problematic aspects on consumerism in this fine synthesis.

The role of intermediaries is also a central concern of William Leach in Land of Desire: Merchants, Power, and the Rise of a New American Culture (1993). For Leach, the intermediaries - brokers, in his terminology - aided business in general, not necessarily particular firms, by advancing the values and institutions of consumer culture. These brokers included, in Leach's conception, window dressers and art school 
instructors as well corporate lawyers and investment bankers. Much more critical of business than Blaszczyk, Leach nevertheless shares her concern with the material and visual environment of consumption, and in particular the role of these intermediaries in creating a commercial culture of "light and color" in the early twentieth century.

As these examples suggest, the study of consumption has become a major feature of American business history as the paradigm has yielded to more diverse approaches. Advertising and marketing as business practices and strategies had, of course, been significant parts of the field's agenda, but in the last quarter-century or so, the perspective has shifted and expanded, without abandoning the insights of the Chandlerian approach. I may confess that my own book on the history of advertising, The Making of Modern Advertising (1983), took a narrower approach. Unimpressed with studies of advertisements that focused almost entirely on their styles and symbols, I began my book with a "no contest" plea to an accusation of economic determinism. In the intervening years, I've learned that advertising history can be sensitive to cultural context without neglecting its business functions. Anthropologists can benefit from many such works. Here are some examples.

Roland Marchand's two classic works, Advertising the American Dream (1985) and Creating the Corporate Soul (1998), are perhaps most notable for incorporating perspectives from art history and art criticism, but to my mind they also excel in depicting the cultural significance of advertising and public relations. His masterful dissections of the "social tableaux," "parables," and "visual clichés" of interwar promotion stand as models of analysis of communicative action. Also of likely interest to anthropologists in Advertising the American Dream is Marchand's depiction of advertising agency life in the 1920s, a remarkable piece of retrospective ethnographic analysis of a business subculture.

Another work in the history of advertising that successfully blends cultural and business history is Pamela Laird's Advertising Progress: American Business and the Rise of Consumer Marketing. Laird's consideration of the multiple meanings of progress in Gilded Age and Progressive Era America, and her examination of the material culture artifacts of businesses - trade cards, store displays and the like - in late nineteenth century America, provided a deeper insight into the messages and meanings of advertising than narrower examinations of advertising simply as a business strategy.

Work and labor is the other area that has benefited most from recent developments in business history. A fascinating example of this is an article by Kenneth Lipartito that blends business history with the history of technology and gender analysis as well as labor history, "When Women Were Switches: Technology, Work and Gender in the Telephone Industry, 1890-1920." (American Historical Review, 1994:4, 1075ff) Lipartito offers a subtle, elegant account of the Bell System's choice to 
stay with manual operators (labeled "Hello Girls") well after mechanical switching equipment became available. Gendered assumptions about women workers, a ready supply of them, and fears that telephone callers would have difficulties interacting with mechanized systems all went into Bell's decision. Ultimately, however, the advantages of mechanization won out in the World War I era as the supply of "suitable" young women shrank and the expansion of the system made manual switching increasingly impractical.

The perspective of labor historians has broadened too, and several recent studies take business strategies and corporate cultures into account in complex fashion. Because of their attention to these factors, they may also interest business anthropologists. I am less familiar with the literature of labor history than consumption history, but I would like to recommend three books. The subtitle of Jefferson Cowie's Capital Moves: RCA's Seventy-Year Quest for Cheap Labor summarizes his thesis, but this is a sophisticated Marxist treatment of the company's shifts from Camden, New Jersey, to maquiladora production in Ciudad Juarez. Gender and urban history complicate and complement the story of the company's labor policies and strategies.

\section{Bethany Moreton, To Serve God and Wal-Mart: The Making of}

Christian Free Enterprise, provides a nuanced and not entirely unsympathetic reading of the corporation that is, in many respects, as much a cultural as a business institution. The regional subculture of the Ozarks, the rise of Evangelical Protestantism, the synthesis of free market and social issue conservative politics, and women's changing roles in the family as well as the labor force, are not merely contexts for Wal-Mart's growth. In fact, Moreton shows, the company has been an active player in shaping those phenomena. Moreton is a contributor to a volume edited by labor historian Nelson Lichtenstein, Wal-Mart: The Face of Twenty-FirstCentury Capitalism; and Lichtenstein, in turn, is the author of an excellent general history of the retail giant, The Retail Revolution: How Wal-Mart Created a Brave New World of Business.

Finally, Joseph McCartin's Collision Course: Ronald Reagan, the Air Traffic Controllers and the Strike that Changed America might seem from its title like a conventional labor history of a strike, with a nod to national politics. However, in fact, it is a densely textured story of a subculture, mainly male, of men at their intense, demanding jobs, in the labor organization they founded, and in their hours with family and friends. The controllers' work and lives - and their interactions with the Federal government and the airline industry - brought a generally conservative group (the union had endorsed Reagan in the 1980 Presidential campaign) to its disastrous 1981 strike. The strike in turn reshaped labormanagement relations in the succeeding generation. Oral histories are a key source for this historically-grounded study. Business anthropologists may not come away from McCartin's book with a deep sympathy for the 
controllers' struggle, but they will certainly gain insights into the cultural dimensions of labor-management relations.

Are business history and business anthropology ready to tie the knot? Probably not. Our disciplinary backgrounds, research sources and standard modes of explanation - diachronic for historians, synchronic for anthropologists - will likely preserve a degree of distance. That business anthropologists are more likely to be working for firms than business historians is another indication of the gap. No anthropologist is among the authors of essays in Franco Amatori and Geoffrey Jones's Business History around the World. The recent Oxford Handbook of the History of Consumption, edited by Frank Trentmann, has thirty-five contributors, none housed in an Anthropology Department. (Both of these volumes, incidentally, can be highly recommended for any anthropologist who is looking for a "state of the field" overview.)

Nevertheless, trends in business history have enabled it to draw closer to anthropology, to make use of anthropological concepts and methods, and to create historical studies that anthropologists with an interest in business should find stimulating and appealing. I've offered some suggestions for those who may want to explore the terrain. In return, I'm sure the Journal of Business Anthropology and practitioners in the field can provide me and other historians with comparable insights from their side. Historians and anthropologists ought to do business with each other.

\section{References}

Amatori, F. and Jones, G. 2003 Business History around the World. Cambridge, England and New York: Cambridge University Press.

Blaszczyk, R. 2009 American Consumer Society, 1865-2005: From Hearth to HDTV. Wheeling, Ill.: Harlan Davidson.

Blaszczyk, R. 2000 Imagining Consumers: Design and Innovation from Wedgwood to Corning. Baltimore, Md.: Johns Hopkins University Press.

Chandler, A. 1990 Scale and Scope: The Dynamics of Industrial Capitalism. Cambridge, Mass.: Belknap Press, 1990.

Chandler, A. 1977 The Visible Hand: The Managerial Revolution in American Business. Cambridge, Mass.: Belknap Press.

Cowie, J. 1999 Capital Moves: RCA's Seventy-Year Quest for Cheap Labor. Ithaca, N.Y.: Cornell University Press.

Galambos, L. 1970 "The Emerging Organizational Synthesis in Modern American History." Business History Review 44 (3): 274-285.

John, R. 1977 “Elaborations, Revisions, Dissents: Alfred D. Chandler, Jr.'s, 'The Visible Hand' after Twenty Years.” Business History Review 72 (1):

151-200. 
Laird, P. 1998 Advertising Progress: American Business and the Rise of Consumer Marketing. Baltimore, Md.: Johns Hopkins University Press.

Lichtenstein, N. 1999 The Retail Revolution: How Wal-Mart Created a Brave New World of Business. New York: Metropolitan Books

Lichtenstein, N. ed. 2006 Wal-Mart: The Face of Twenty-First Century Capitalism. New York: New Press.

Lipartito, K. 1994 "When Women Were Switches Technology, Work and Gender in the Telephone Industry, 1890-1920." American Historical Review 99 (4): 1074-1111.

Leach, W. 1993 Land of Desire: Merchants, Power, and the Rise of a New American Culture. New York: Pantheon Books.

McCartin, J. 2011 Collision Course: Ronald Reagan, the Air Traffic Controllers and the Strike that Changed America. New York: Oxford University Press.

Marchand, R. 1985 Advertising the American Dream: Making Way for Modernity, 1920-1940. Berkeley: University of California Press.

Marchand, R. Creating the Corporate Soul: the Rise of Public Relations and Corporate Imagery in American Big Business. Berkeley: University of California Press.

Moreton, B. 2009 To Serve God and Wal-Mart: The Making of Christian Free Enterprise. Cambridge, Mass.: Harvard University Press.

Scranton, P. 1997 Endless Novelty: Specialty Production and American Industrialization, 1865-1925. Princeton, N.J.: Princeton University Press.

Scranton, P. 1989 Figured Tapestries: Production, Markets and Power in Philadelphia Textiles 1885-1941. Cambridge, England and New York: Cambridge University Press.

Trentmann, F. 2012 The Oxford Handbook of the History of Consumption. Oxford and New York: Oxford University Press.

Wiebe, R. 1967 The Search for Order: 1877-1920. New York: Hill \& Wang.

Greg Urban is the Arthur Hobson Quinn Professor of Anthropology and former Chair of the Department of Anthropology at the University of Pennsylvania. A specialist in linguistic and cultural anthropology, Urban studies the processes of cultural motion, with a focus on the forces that impel that motion through space and time. He has done extensive research among indigenous populations in Brazil, and is now also interested in modern business corporations as institutional loci for the creation of new culture. Among his books are: Metaculture: How Culture Moves through the World, Metaphysical Community: The Interplay of the Senses and the Intellect, and, as editor, Corporations and Citizenship. He may be reached at gurban@sas.upenn.edu 